NBER WORKING PAPER SERIES

\title{
SURVEY UNDER-COVERAGE OF TOP INCOMES AND ESTIMATION OF INEQUALITY: WHAT IS THE ROLE OF THE UK'S SPI ADJUSTMENT?
}

\author{
Richard V. Burkhauser \\ Nicolas Hérault \\ Stephen P. Jenkins \\ Roger Wilkins \\ Working Paper 23539 \\ http://www.nber.org/papers/w23539 \\ NATIONAL BUREAU OF ECONOMIC RESEARCH \\ 1050 Massachusetts Avenue \\ Cambridge, MA 02138 \\ June 2017
}

This research is supported by an Australian Research Council Discovery Grant (award DP150102409). In addition, Burkhauser over the past three years has received funding in excess of $\$ 5,000$ from the American Enterprise Institute; the Employment Policies Institute; and the Lynde and Harry Bradley Foundation Graduate and Post-Graduate Fellowship Program. Hérault over the past three years has received funding in excess of \$5,000 from an Australian Research Council Discovery Grant, the New Zealand Treasury and RFi Analytics. Jenkins over the past three years has received funding in excess of \$5,000 from the Research Centre on Micro-Social Change at the Institute for Social and Economic Research by the University of Essex and the UK Economic and Social Research Council (award ES/L009153/1). Wilkins over the past three years has received funding in excess of \$5,000 from the Australian Government Department of Social Services, the Australian Fair Work Commission, and the Australian Workforce and Productivity Agency. For helpful discussions about the HBAI data and SPI adjustments, we thank Peter Matejic and his DWP colleagues and Jeremy Reuben from HMRC's SPI team. We gratefully acknowledge the perceptive comments of three anonymous referees. The findings and views reported in this paper are those of the authors and should not be attributed to any of the abovementioned persons or organizations, or to the National Bureau of Economic Research.

NBER working papers are circulated for discussion and comment purposes. They have not been peer-reviewed or been subject to the review by the NBER Board of Directors that accompanies official NBER publications.

(C) 2017 by Richard V. Burkhauser, Nicolas Hérault, Stephen P. Jenkins, and Roger Wilkins. All rights reserved. Short sections of text, not to exceed two paragraphs, may be quoted without explicit permission provided that full credit, including $\odot$ notice, is given to the source. 
Survey Under-Coverage of Top Incomes and Estimation of Inequality: What is the Role of the UK's SPI Adjustment?

Richard V. Burkhauser, Nicolas Hérault, Stephen P. Jenkins, and Roger Wilkins

NBER Working Paper No. 23539

June 2017

JEL No. C81,D31

\section{$\underline{\text { ABSTRACT }}$}

Survey under-coverage of top incomes leads to bias in survey-based estimates of overall income inequality. Using income tax record data in combination with survey data is a potential approach to address the problem; we consider here the UK's pioneering 'SPI adjustment' method that implements this idea. Since 1992, the principal income distribution series (reported annually in Households Below Average Income) has been based on household survey data in which the incomes of a small number of 'very rich' individuals are adjusted using information from 'very rich' individuals in personal income tax return data. We explain what the procedure involves, reveal the extent to which it addresses survey under-coverage of top incomes, and show how it affects estimates of overall income inequality. More generally, we assess whether the SPI adjustment is fit for purpose and consider whether variants of it could be employed by other countries.

Richard V. Burkhauser

University of Texas-Austin

Department of Economics

2225 Speedway, Austin, TX 78712

and University of Melbourne

and Cornell University

and also NBER

rvb1@cornell.edu

Nicolas Hérault

Melbourne Institute of Applied Economic and

Social Research

Level 5, 111 Barry St

Carlton, VIC 3053

nherault@unimelb.edu.au
Stephen P. Jenkins

Department of Social Policy

London School of Economics

and Political Science

Houghton Street

London WC2A 2AE

United Kingdom

s.jenkins@lse.ac.uk

Roger Wilkins

Melbourne Institute of Applied Economic

and Social Research

University of Melbourne

Faculty of Business and Economics Building

5th floor

Victoria 3010, Australia

r.wilkins@unimelb.edu.au 


\section{Introduction}

Survey under-coverage of top incomes leads to bias in survey-based estimates of overall income inequality. Using income tax record data in combination with survey data is a potential approach to address this problem because tax data are likely to have much better coverage of top incomes. In this paper, we consider a pioneering variant of this approach (the 'SPI adjustment') long employed in the UK official income distribution statistics, assess its strengths and weaknesses for measuring income inequality, and discuss the extent to which the approach might be applied in other countries.

That insufficient income from top income groups is captured by household surveys is discussed in the 'top incomes' literature. Atkinson et al. highlight various problems with surveys, stating that 'such problems particularly affect the top income ranges' (2011:29). They illustrate their argument by showing how estimates of the share of total income held by the top 1\% derived from the US Current Population Survey (CPS) fall below the estimates derived from Internal Revenue Service Survey of Income (IRS-SOI) personal tax return data, even after the CPS estimates have been adjusted upwards to account for their top-coding (Burkhauser et al. 2012): 'CPS data that do not measure top incomes fail to capture about half of [the] increase in overall inequality' between 1976 and 2006 (Atkinson et al. 2011: 32). More recently, the under-coverage problem has been highlighted by OECD economists interested in cross-national inequality comparisons as well as national trends:

On the one hand, inequality figures drawn from household surveys measure income dispersion on a comprehensive and representative portion of the population, but are not able to capture top incomes. Yet it is in this portion of the distribution that most of the changes in inequality seem to have occurred over the last fifteen years ... This implies in particular a systematic underestimation of inequality levels based on surveys. On the other hand, figures derived from tax return data offer an accurate picture for top incomes, but remain mute about how top incomes fit in the overall distribution and what are the global inequality trends: in particular, the complete evolution of inequality in a country where top incomes shares increase but where inequality across the rest of the population decreases cannot be determined. (Ruiz and Woloszko, 2015: 6).

Relatively few people are aware that the UK principal income distribution series has long incorporated an adjustment method intended to address these issues. And no other 
country in the world employs such a method (as far as we know), although survey undercoverage of top incomes is a potentially universal issue.

We examine the 'SPI adjustment' methodology that Department for Work and Pensions statisticians use to modify the incomes of very rich respondents to the Family Resources Survey, drawing on data from very rich individuals in the Survey of Personal Incomes, a very large sample of the records for people liable to pay UK personal income tax held by Her Majesty's Revenue and Customs (HMRC). The SPI-adjusted survey income data are the basis of the annual income distribution report Households Below Average Income (see e.g. Department for Work and Pensions 2016a) and the Institute for Fiscal Studies' annual commentaries on inequality and poverty (see e.g. Belfield et al. 2016). The data are also used by many other researchers because they are made available in unit record form through the UK Data Service.

The SPI adjustment was a pioneering innovation when introduced almost a quarter of a century ago (1992), but its methodology merits new scrutiny. The SPI adjustment affects estimates of income inequality, including the shares of total income held by different groups (e.g. the top 1 per cent of income-receivers) as well as summary indices such as the Gini coefficient used to summarize the inequality of income for the population as a whole. ${ }^{1}$ Given the growing prominence of debates about inequality levels and trends in public discussion, it is important to get the inequality estimates right and this requires examination of the data used to calculate them.

In this paper, we review the SPI adjustment's key features and analyse its effects on the shape of the income distribution at the top end and on measures of overall inequality. Our work will help research users to understand the methods and it will provide input to assessments about whether the adjustment could and should be modified or indeed applied in other countries. No substantive explanation of the SPI adjustment currently exists. There are only scattered sources (often unpublished) and some features are not documented at all.

We also assess the SPI adjustment methodology against its own goals. Originally, these were ' $[\mathrm{t}] \mathrm{o}$ improve the quality of data on very high incomes and combat spurious volatility' (Department for Work and Pensions 1996: 23) but, in recent years, the adjustment refers only to the second aspect, i.e. 'to correct for volatility in the highest incomes captured in the survey' (Department for Work and Pensions 2016b: 20). We show that the SPI adjustment makes more changes to the data than are required to reduce problematic volatility,

\footnotetext{
${ }^{1}$ Estimates of low-income prevalence are unaffected because the low-income cut-offs used in Households Below Average Income are all defined as fractions of median income, and the median is unaffected by the SPI adjustment.
} 
and we argue that there are potentially better ways to improve data quality at the top of the income distribution. ${ }^{2}$

In Section II, we briefly explain the survey and tax data sources. We describe the SPI adjustment in Section III, explaining what we know and do not know about the method. We draw attention to issues associated with the adjustment's use of stratification groups and the way it estimates the values and numbers of 'very rich' incomes using projections from earlier years' data. In Section IV we assess survey under-coverage using comparable tax data as the benchmark, and we analyse the extent to which this problem is addressed by the SPI adjustment. Next we show the effects of the SPI adjustment on estimates of inequality summarized by the Gini coefficient, the principal measure used in the UK and most other countries (Section V). Section VI contains further discussion and conclusions, including remarks about the extent to which the UK's approach could or should be modified or implemented in other countries. Additional tables and figures appear in appendices.

\section{Survey data and tax data on incomes}

The household survey from which the main UK survey-based income series are derived is the Family Resources Survey (FRS), a continuous survey of the private household population that is administered by the Department for Work and Pensions (DWP). Each year, a new sample is drawn, with an achieved sample size of approximately 25,000 respondent households each year up until 2010, and a sample size of approximately 20,000 since 2011. The FRS began in fiscal year 1994/95 and we use the yearly data through to 2014/15.

DWP statisticians derive three distinct income distribution series from the FRS annually. The first series, which we label 'FRS', is based on the survey responses and includes sample weights and basic imputations for item non-response (see e.g. DWP 2016b). The second series ('HBAI') is a further cleaned-up series which also incorporates additional derived income variables employing definitions of income and income-receiving unit that are employed in the DWP's Households Below Average Income report. The third series ('HBAISPI') is the SPI-adjusted HBAI series - the data from which the report's statistics are calculated, and the derivation of which we discuss in detail in the next section.

\footnotetext{
${ }^{2}$ We do not examine data quality at the bottom of income distribution. For a recent UK study examining this issue, see Brewer et al. (2015).
} 
The values of HBAI-SPI income variables differ from their HBAI counterparts only for the limited number of individuals (and the corresponding households and benefit units) subject to the SPI adjustments to their incomes, although SPI adjustments also involve changes to grossing-up weights that extend further down the income distribution (see below).

'Income' in the HBAI and the HBAI-SPI series used in Households Below Average Income refers to equivalised net (i.e. disposable) household income, with individuals attributed with the income of the household to which they belong. Net household income includes income from employment and self-employment, income from investments and savings, cash benefits and credits from the government, and private transfers, from which is deducted payments of personal income tax, employee National Insurance contributions, local (Council) tax payments, and some other deductions. The adjustment for differences in household size and composition uses the modified-OECD equivalence scale. See DWP (2015) for further details.

The tax return data used for the SPI adjustment come from the Survey of Personal Incomes (SPI), administered by Her Majesty's Revenue and Customs (HMRC). Each fiscal year's SPI is a stratified sample of all tax returns. The number of individuals in the sample has increased from around 57,000 in $1995 / 6$ to nearly 677,500 in $2010 / 11$, corresponding to around 32 million taxpayers. Individuals cannot be linked across years of the SPI, or to other taxpayers from the same family or household within the same year, or to FRS survey respondents. Our analysis throughout is based on SPI data for 1995/96 through to 2010/11, i.e. the period for which SPI public use tax return unit record data are available (with the exception of $2008 / 09$, for which there are no data). ${ }^{3}$

The principal income variable available in the SPI is individual gross income, reflecting the rules of the UK personal tax system (individual-based since 1990). Gross income is total taxable income from the market plus taxable government transfers, and before the deduction of income tax. (It is the variable that the top income shares literature focuses on.)

With access to the FRS unit record data about income components, it is possible to create an individual gross income variable in the survey data, and hence reconcile and combine survey and tax data using appropriately comparable definitions in each source. Also for comparability's sake, we sometimes restrict attention to individuals aged 15 years or more

\footnotetext{
${ }^{3 ،}$ The 2008-09 SPI is still unavailable but HMRC remains committed to producing the 2008-09 SPI' (HMRC 2016a: 3). Since we began our research, unit record SPI data for 2013/14 have been released but not those for $2011 / 12$ or $2012 / 13$.
} 
in both sources. For further details of income variable construction and samples, see Burkhauser et al. (2016: Section 2).

\section{The SPI adjustment}

In principle, each year's SPI adjustment is straightforward:

- Identify 'very rich' individuals in the survey A respondent is counted as 'very rich' if his or her income is above a threshold, where the threshold depends on whether the respondent is a pensioner or non-pensioner and on whether the respondent resides in Great Britain (England, Wales, and Scotland) or Northern Ireland.

- Impute cell-means The income of each 'very rich' respondent in the FRS is replaced by the mean income of a corresponding group of 'very rich' individuals in the SPI data.

- Recalibrate weights The numbers of 'very rich' individuals in the population is estimated from the SPI. The survey grossing factors (weights) are then recalibrated using the numbers of high-income pensioners and non-pensioners as control totals, in addition to the many other control totals used to derive the grossing-up factors for FRS and HBAI data. $^{4}$

This brief description omits important details, including how each element has changed over time. We now elaborate. An important part of our story is to explain that external users cannot replicate all the internal DWP and HMRC procedures, either because particular variables are unavailable in public use files, or because of a lack of documentation. The main documentation of the SPI adjustment is a single page in the Quality and Methodology Information Report accompanying the HBAI report (see e.g. DWP 2016b: 20). ${ }^{5}$ We have gleaned more details from earlier Methodological and Quality reviews (e.g. DWP 1996, 2004), unpublished internal DWP papers (Gray 2007; Matejic n. d.), discussions with DWP and HMRC staff, and our own analysis of HBAI and HBAI-SPI public-use data.

\footnotetext{
${ }^{4}$ The DWP derives grossing factors (weights) for both the HBAI and HBAI-SPI using a widely-used calibration weighting methodology. External data from official sources about population characteristics are used to define control totals. The grossing factors selected are those that minimize the 'distance' between weighted survey distributions and the population distributions. See Department for Work and Pensions (2016b: 16-19).

${ }^{5}$ Similar information is provided in one page by Belfield et al. (2016: 85).
} 


\section{The definition of a 'very rich' individual}

The DWP determine the eligibility for the SPI adjustments each year at the individual level using income thresholds above which individuals are deemed 'very rich'. The thresholds are set at a level above which, for each group, the FRS data are considered to be 'volatile due to the small numbers of cases' (Department for Work and Pensions 2016b: 20).

Different thresholds are used for pensioners and non-pensioners and, from 2002/03, for Great Britain and Northern Ireland. For example in 2012/13, 'non-pensioners in Great Britain are subject to the SPI adjustment if their gross income exceeded $£ 236,694$ per year ( $£ 131,166$ per year in Northern Ireland) and pensioners in Great Britain are subject to the SPI adjustment if their gross income exceeded $£ 73,631$ per year $(£ 60,088$ per year in Northern Ireland)' (Department for Work and Pensions 2014a: 11). For a full list of the income thresholds for all years and all groups, see Appendix Table A1.

Up until 2008/09, the threshold for non-pensioners was based on net (disposable) income but, since 2009/10, it has been based on gross income. The other change introduced in 2009/10 was to base 'the SPI adjustment methodology [...] on adjusting a fixed fraction of the population rather than on adjusting the incomes of all those individuals with incomes above a fixed cash terms level. This should prevent an increasing fraction of the dataset being adjusted' (Department for Work and Pensions 2011: 242).

Using fixed (nominal) thresholds before 2009/10 led to a varying but generally increasing share of the population being subject to the adjustment. (For further details, see Table 2 discussed in Section IV, and also Appendix Table A2.) Since 2009/10, the target has been to adjust at most around $1 / 2$ per cent of (weighted) survey observations overall, though hitting the target exactly is constrained by the use of four stratification groups. Our investigations indicate that the actual adjustment rule has been to adjust the top 0.3 per cent of non-pensioners (top 0.3 per cent in GB and top 0.3 per cent in NI) and the top 1.1 per cent of pensioners (top 1.1 per cent in GB and top 1.1 per cent in NI). Consequently, in practice, the total fraction of the population adjusted fluctuates slightly from year to year. That is, the difference in the relative threshold for pensioners and non-pensioners and changes in the population shares of the four stratification groups lead to slight fluctuations over time in the total size and composition of the group subject to the SPI adjustment.

A more fundamental issue is why the stratification groups are defined as they are.

When the FRS started it had no respondents from Northern Ireland (by design) and hence the SPI adjustment referred to households from Great Britain only. When the FRS was extended 
to Northern Ireland, from 2002/3, it appears that the decision was taken to define a new stratification category rather than to change the existing methodology. Gray (2007: 1) states that the rationale for the distinction between pensioners and non-pensioners 'is because nonpensioners are more likely to have higher incomes compared to pensioners, so a threshold above which some pensioners were considered to be 'rich' may be too low a threshold for some non-pensioners to be deemed 'rich'. Also, we look at pensioners separately as we are carrying out an adjustment on behalf of the Pensioner Incomes Series who use the HBAI data.' (The DWP also produce a separate Pensioner Income Series annually that uses HBAI income variables: see e.g. DWP 2014b.) We are not fully persuaded by the logic of the arguments, and return to the issue of stratification groups in Section VI.

\section{Estimating the number of 'very rich' individuals and their incomes}

The number of 'very rich' individuals in the UK population, and the average (mean) income of each type of 'very rich' individual, are estimated using SPI data. Gray (2007) describes the steps taken to do this each year, but important details are undocumented.

Given the income thresholds chosen for the year in question, DWP statisticians request the HMRC staff administering the SPI to provide estimates of (a) the numbers of 'very rich' individuals in each top-income group, and (b) each group's average income.

On receipt of these estimates, the DWP statisticians replace the individual gross income for each individual in the HBAI data who is above the relevant income threshold with the cell-mean estimate derived from the corresponding group in the SPI.

Finally, some subsequent adjustments are made that re-incorporate some survey information. In particular, the DWP statisticians 'add back in other deductions [...] but exclude personal pension payments [...] as these are not included in the SPI definition of net income. We also take out any housing benefit as this is arbitrarily allocated to the head of the benefit unit and doesn't necessarily constitute part of their individual income' (Gray 2007: 3). These final adjustments mean that 'very rich' individuals within each of the four adjustment groups may have not exactly the same income. But because these subsequent adjustments are limited in scale, they have small effects on the income distribution.

The procedures used by the SPI team are the most difficult aspect to assess because there is no documentation. Here follows what we have been able to ascertain. 
The numbers of 'very rich' individuals and their average income in a given survey year are projected using SPI data from an earlier year because SPI data for the given survey year are unavailable at the time at which DWP statisticians create the HBAI and HBAI-SPI data. For example, '[t]he 2013/14 estimates were projections based on 2012/13 data' (DWP 2015: 11). From our reading of Households Below Average Income documentation, the projections were also based on SPI data from one year earlier than the HBAI data for the estimates for each year from 2009/10 through to 2011/12, and also 2003/04. For 2002/03 and 2004/05 through to $2009 / 10$, the projections were based on SPI data from two years earlier. What was done before 2002/03 is undocumented.

Getting the number of very rich individuals and their incomes correct has a direct effect of estimates of inequality in SPI-adjusted income distributions, since the greater the total income (and population share) attributed to this group, the greater will the estimate be. (This is a separate issue from assessing the nature of survey under-coverage: see Section IV.)

For the details of the projection method, the SPI team (in personal correspondence) directed us to Appendix B of HMRC's Income Tax Liabilities statistical release (HMRC $2016 b$ ). The main aim of the release is to provide outturn and projection statistics for individual income taxpayer numbers, income tax liabilities and average rates of tax broken down by taxpayer characteristics, i.e., the calculations are not directly tailored to the needs of Households Below Average Income, which seeks to estimates the numbers of very rich people and their incomes. In a nutshell, the projections are based on individual reweighting (using ONS population projections) and on income growth projections by income source based on the Office for Budget Responsibility forecasts and recent trends from the ONS Annual Survey of Hours and Earnings (ASHE). Except for labour earnings, for which ASHE trends are assessed separately for the richest $10 \%$ to $5 \%$ and the top $5 \%$ of taxpayers, the projection method is not specifically designed to predict differential changes by income group. Thus projection errors for top income groups (of total income and hence income shares) could potentially be quite large. The projection methods appear to have been broadly the same since 2011 , but there is no information about the years before that.

In principle, it should be possible to evaluate the accuracy of the SPI projections by comparing them with the subsequent outturn SPI values. To do this, for each of the four stratification groups, the mean income in the year $t$ SPI outturn would be compared with the mean income in the year $t$ HBAI-SPI data (which is the projected SPI value for year $t$ ). And 
the numbers of very rich people can also be compared. However, 2010/11 is the only year in which the stratification group of each observation can be identified in the SPI outturn data, since this is the only year in which the dataset contains a 'state pension age' flag. For all other years, it is not possible to accurately determine pensioner status for all individuals. (Whether the individual resides in GB or NI is identifiable in all years.) Consequently, $2010 / 11$ is the only year it is possible to ascertain the mean income in the SPI for each of the four stratification groups. We therefore focus first on 2010/11, and then consider what we can say about earlier years.

Table 1 shows that the projection for the total income of all individuals in the four stratification groups, $£ 78.7$ billion, is around $£ 6.1$ billion below the SPI outturn ( $£ 84.8$ billion) in 2010/11. There are variations in projection errors across stratification groups. For example, the projections overestimated mean income for GB non-pensioners $(£ 527,635$ versus $£ 492,173$ ) but underestimated the number of individuals over the corresponding income threshold $(112,998$ versus 136,186$)$. The net effect was that total income for GB nonpensioners was $£ 7.4$ billion less than the SPI outturn. By contrast, total income for GB pensioners was $£ 1.1$ billion larger than the SPI outturn. For the two GB groups, and for all groups combined, the outturn values differ by more than two standard errors from the projected values.

\section{$<$ Table 1 near here $>$}

Assessment of projection error for 2010/11 is complicated by changes in the UK tax system that led to behavioural response. A 50\% top marginal rate of income tax was introduced in April 2010 (up from 40\%), and the announcement and introduction of this tax rate provided incentives for high income taxpayers to bring forward income to 2009/10 that would otherwise have been reported in 2010/11 income tax returns or possibly later years. This is the process of 'forestalling'. Subsequently, a reduction in the top marginal tax rate to $45 \%$ provided incentives to defer income to later tax years ('reverse forestalling'). See HMRC (2012) and Seely (2014) for further discussion.

In short, the 2010/11 undershoot in the projected total gross income for very rich individuals may be due to these changes, especially when one notes that the undershoot is driven by the GB non-pensioner group, the group most likely to contain high-income taxpayers.

However, our examination of projection error looking at earlier years, i.e. when there were no forestalling issues, provides suggestive evidence of a more systematic problem with the projection method. Given the banded age data available in the SPI in most years, it is only 
for women aged 55-64 that we cannot infer pensioner status. (The state retirement pension age for women was 60 years.) Hence it is possible to extend the projection-outturn comparisons shown in Table 1 for 2010/11 to earlier years if we exclude women aged 55-64 from both the HBAI-SPI and SPI datasets, but not to years before 1997/98 because age information is not provided in the SPI data before then. Comparisons based on data implementing this exclusion are shown in Appendix Table A3 for 1997/98 through 2009/10.

The patterns for 2010/11 describe earlier years as well. Projections of total income systematically undershoot outturns, with the difference ranging from between $3 \%$ in 2001/02 and $28 \%$ in 2006/07. There is one exceptional year, 2002/03, in which the Great Britain projection overshoots total income outturns, possibly reflecting the incorporation of Northern Ireland into the FRS that year. In all other years, although projections of mean incomes tend to be overestimates of outturns, this is more than offset by the underestimation of the numbers of individual affected. ${ }^{6}$ To the extent that the systematic undershooting of total income for the very rich translates into undershooting of their income shares, it would appear that over the past two decades, the HBAI-SPI projection methodology has generated estimates of inequality levels that are lower than would have been calculated had SPI outturn data been available. This is a separate issue from survey under-coverage per se, to which we now turn.

\section{Survey under-coverage of top incomes and the effect of the SPI adjustment on 'very rich' individuals}

This section first examines the extent of under-coverage of top incomes in the survey data using SPI data as a benchmark. Second, we focus on the 'very rich' individuals in the HBAI data affected by SPI adjustments each year, and document their numbers and the effects of the adjustment on their income and grossing-up weights.

\section{Survey under-coverage of top incomes}

Survey under-coverage of top incomes may arise because of either under-reporting by very

\footnotetext{
${ }^{6}$ This is despite the small downward bias in the estimates of the projected mean incomes arising from ignoring the potential increase in the cell means due to the exclusion of women aged 55-64. The impact of this exclusion is likely to be relatively small because this subgroup is likely to form a small fraction of the people counted as 'very rich'.
} 
rich respondents to the survey, or lower survey participation rates (unit non-response) by very rich households, or both. We believe that under-reporting is the most important (but not the only) factor, on the grounds that the values of the top income percentiles (such as the $90^{\text {th }}$, and especially $95^{\text {th }}$ and $99^{\text {th }}$ percentiles) in the individual gross income distribution that can be constructed from the HBAI data are close in value to the corresponding percentiles in the SPI data. ${ }^{7}$ There is recent evidence that unit non-response plays a relatively small role in the USA as well. Bee et al. (2015) link respondents to the 2011 Current Population Survey to tax return (IRS Form 1040) data and find 'little evidence of differences between the percentiles of the adjusted gross income distribution of the linked respondents and non-respondents' (2015: 3).

We therefore proceed to document survey under-coverage by taking top income groups in the survey data for each year and the corresponding groups in the tax return data and looking at the ratio of group total income in the survey to group total income in the tax data. Ratios below 100 per cent represent under-coverage. Here, for comparability reasons, top income groups refer to the top $x$ per cent of the population aged 15 and over (using the respective SPI and HBAI grossing up factors) and to distributions of individual gross income. The period analysed reflects the availability of the SPI data (1995/96 to 2010/11, with a gap in 2008/09).

Figure 1(a) shows that survey under-coverage of top incomes is a serious problem. Under-coverage is particularly acute at the $99^{\text {th }}$ percentile and above, with reported ratios of 90 per cent or smaller. Furthermore, the small number of respondents underlying the survey estimates results in substantial year-on-year volatility, especially for the top 0.1 percent. However, under-coverage is also an issue further down the distribution, especially in the midto late-2000s. These 'almost very rich' income groups are well below those subject to the DWP's SPI adjustment (approximately the top $1 / 2$ per cent in recent years). In contrast, undercoverage is much less of a problem for the 'top 10 to 5 percent' group for most of the period, with ratios around 100 per cent, though some under-coverage becomes apparent at the end of the period. ${ }^{8}$

$<$ Figure 1 near here $>$

\footnotetext{
${ }^{7}$ For comparability reasons, the distributions in both data sets refer to individuals aged 15 years or more. The data to support our claim are provided by Jenkins (2017, Appendix I). Jenkins takes each HBAI individual gross income top percentile in each year and calculates the percentile in the SPI data that corresponds to that income value. For example, in $2010 / 11,1.1 \%$ of individuals in the SPI data have a gross income that is above $p 99$ in the HBAI data.

${ }^{8}$ Jenkins (2017, Section II) examines under-coverage using ratios of corresponding HBAI and SPI percentiles, supplemented by density comparisons. He reaches the same conclusions about survey under-coverage at the top as reported here.
} 


\section{Individuals in the HBAI affected by SPI adjustments}

Table 2 summarises the effects of the SPI adjustment on individual gross incomes and on grossing up factors of individuals deemed 'very rich' by DWP, for each year over the period 1994/95 to 2014/15. ${ }^{9}$ Columns 1 and 2 show the estimated population share of individuals subject to SPI adjustment with column 1 using the original FRS weights and column 2 the post-SPI adjustment weights. Between 0.09 and 0.36 percent of the weighted FRS sample (using the original FRS weights) are SPI-adjusted each year. In all years other than 1996/97, the estimated population share of these individuals increases as a result of the SPI adjustment, although the magnitude of increase has been larger since 2007/08, since when the weighted population share post SPI adjustment has been approximately $1 / 2$ percent in every year.

$<$ Table 2 near here $>$

The remaining columns of Table 2 show for each year the impacts of the SPI adjustment on the mean income among the individuals whose incomes are adjusted. Column 3 presents estimates of means without the SPI adjustments to either individual incomes or to grossing factors (weights) and column 6 presents estimates of mean incomes after SPI adjustment of both weights and incomes. Columns 4 and 5 show the estimates of means based on adjusting the weights but not the incomes and vice versa. In 2014/15, for example, the SPI adjustment increased the mean gross weekly income of individuals deemed 'very rich’ from $£ 4,521$ to $£ 7,487$. Application of the adjusted individual grossing factors alone increased the mean from $£ 4,521$ to $£ 5,228$ (column 4), whereas adjustment of income values alone increases the mean from $£ 4,521$ to $£ 6,272$ (column 5). Hence, in 2014/15, the main effect of the SPI adjustment occurs through changes to individuals' incomes. This is also the case in most, but not all, other years. When there are one or more extreme outliers in the survey data, the SPI adjustment can act to reduce the mean. This occurs in 2000/01, 2001/02, 2005/06, 2008/09 and 2013/14 (compare columns 3 and 6).

Because Table 2 focuses on mean incomes, it does not reveal that adjustments to incomes or grossing factors can be substantial for some individuals and groups. For instance, Appendix Table A4 shows that in 2014/15 the post-adjustment grossing factor for very rich GB non-pensioners was 117 per cent greater than the pre-adjustment grossing factor. Only for

\footnotetext{
${ }^{9}$ Although SPI outturn data are not available for 2008/09, HBAI-SPI data, which rely on SPI projections, are available for all years from 1994/95 to 2014/15. We report full details of the SPI adjustment effects on individual gross incomes and on grossing-up factors of individuals deemed 'very rich' in Appendix Table A4. The table shows that the number of individual FRS respondents whose incomes are changed by the SPI adjustment is small in absolute number each year, ranging between 45 (in 1995/96) and 175 (2010/11).
} 
a few years does the adjustment involve a reduction in grossing-up factors, reflecting an overrepresentation of the 'very rich' in the survey data relative to the SPI data. ${ }^{10}$

The nature of the SPI adjustment, specifically the way the stratification groups are defined, means that individuals subject to the adjustments are not necessarily the individuals with the highest incomes. For example, although $1 / 2$ per cent of the (post-SPI adjustment) weighted population in 2010/11 was subject to the SPI adjustment, this does not imply that all those in the top $1 / 2$ per cent of the income distribution were subject to the SPI adjustment. The minimum income in the top $1 / 2$ per cent of the individual (pre-SPI adjustment) HBAI gross income distribution in $2010 / 11$ was $£ 136,000$ per year. However, the SPI adjustment thresholds were $£ 65,321$ for pensioners in GB, $£ 57,091$ for pensioners in NI and $£ 131,166$ for non-pensioners in NI, implying that some individuals in these stratification groups were subject to the SPI adjustments even though they were not part of the top $1 / 2$ per cent of the distribution of individual incomes. Conversely, some non-pensioners in GB who were in the top $1 / 2$ per cent were not subject to the SPI adjustment because their income was below the $£ 236,694$ SPI adjustment threshold for non-pensioners in GB in that year. Thus, for 2010/11, we find that there are significant fractions of SPI-adjusted observations spread across the top 2.5 per cent of the distribution, as well as some in the 96.5 to 96.6 percentile groups. There are similar results for other years.

Survey under-coverage means that there is an insufficiently large fraction of the population observed in the top income ranges of the survey data. The DWP's SPI adjustment works by using the information provided by tax data to place more people in the critical ranges. This is illustrated by Figure 2, which shows kernel density estimates of the upper tails of the HBAI and HBAI-SPI distributions of individual gross income in 2010/11. ${ }^{11}$ A higher density at a given income value means a greater concentration of people. We present estimates for distributions of log income, rather than income itself, in order to focus attention on the upper tail, and we deliberately use a small bandwidth in order to bring out the fine structure. The dashed vertical lines mark the $90^{\text {th }}, 95^{\text {th }}, 99^{\text {th }}$, and $99.5^{\text {th }}$ percentiles of the HBAI distribution. The HBAI distribution (grey density line) has a long right hand tail with a very tiny amount of density mass. The maximum observed value is approximately $£ 3.54$ million, and the next three highest values are $£ 1.39$ million, $£ 1.25$ million, and $£ 1.14$ million. The DWP's SPI adjustment replaces the sparse upper tail in the HBAI distribution with just two distinct clumps of density mass (for the non-pensioner groups), as shown by the dashed

\footnotetext{
${ }^{10}$ Specifically, grossing-up factors were reduced for GB non-pensioners in 1994/95, 1996/97, 1997/98 and $2000 / 01$, and for NI non-pensioners in 2002/03 and 2004/05.

${ }^{11}$ For comparisons of HBAI and SPI distributions for each year, see Jenkins (2017, Figure 2 and Appendix A).
} 
density line. The effect of changing the incomes of individuals in the two 'very rich' pensioner groups is imperceptible.

$<$ Figure 2 near here $>$

We now return to Figure 1 and show how under-coverage in the HBAI is mitigated by the SPI adjustment. Figure 1(a) examines under-coverage of the HBAI by presenting the ratio of HBAI income to SPI income for percentile groups in the top 10 per cent of the income distribution. Figure 1(b) presents analogous information for the HBAI-SPI, showing the ratio of HBAI-SPI income to SPI income for the same top income groups. Across the 1995/96 to 2010/11 period, there is no noticeable difference between the HBAI and HBAI-SPI series for the top 10 per cent to 5 per cent income groups. This is what one expects since the SPI adjustment does not impact on incomes in this part of the distribution.

But comparison of Figures 1(a) and 1(b) shows that the SPI adjustment manages to bring the survey estimates closer to the SPI estimates. In particular, the gap is greatly reduced for the top 2 per cent to 1 per cent group (i.e., the 99th percentile group) and for the top 1 per cent to 0.5 per cent group.

Moreover, there remain differences in coverage between those in the top 0.5 per cent to 0.1 per cent group and those in the top 0.1 per cent, because the SPI adjustment calculates its cell means among stratification groups in which there is a wide range of incomes. ${ }^{12}$ The SPI adjustment tends to impute income values that are too large for those in the top 0.5 per cent to 0.1 per cent group, but too small for the top 0.1 per cent. Hence, mean income for the top 0.5 per cent to 0.1 per cent group tends to be higher in the HBAI-SPI than in the SPI (31 per cent higher in 2009/10) but smaller for the top 0.1 per cent (up to 50 per cent smaller, in 2007/08). This suggests that one way to improve on the SPI adjustment would be to use a more finely granulated approach to better reflect inequality among top incomes.

In summary, the last two sections have shown how the SPI adjustment is implemented (subject to the caveat that many important details are undocumented), and raised questions about its stratification groups and projection methodology. We have demonstrated that the SPI adjustment improves coverage of top incomes relative to a tax data benchmark, but it is less successful at doing so the further up the distribution we go. But the more important lesson is that the SPI adjustment does not reach far enough down the distribution. Figure 1 shows that FRS under-coverage of top incomes stretches beyond the income range to which the SPI adjustment is applied. We return to these points in Section VI.

\footnotetext{
12 This general point aside, the post-SPI adjusted series shows a marked deterioration in the coverage of the top 0.1 per cent after $2002 / 03$. It is unclear what is driving this.
} 


\section{The impact of the SPI adjustment on measures of inequality}

The importance of the SPI adjustment for assessing UK income inequality levels and trends is highlighted by a comparison of the official series of Gini coefficient estimates for the UK. ${ }^{13}$ See Figure 3.

The principal official series is the FRS-based HBAI-SPI series produced by the DWP that is discussed earlier. The ONS-ETB series is from the ONS's annual commentary on 'the effects of taxes and benefits on household incomes' (e.g. ONS 2016), and is derived from the Living Costs and Food Survey. The ONS-EUSILC series, which began in 2005/06, is the series that the UK contributes to the EU's social inclusion statistics through EU-SILC. It was initially based on the General Lifestyle Style and since 2012 has been based on the FRS.

Neither of the two ONS series incorporates an SPI adjustment. All three series refer to household disposable income equivalised using the modified-OECD scale (rather than the measure of individual gross income to which the SPI adjustment is made). In the HBAI-SPI and ONS-EUSILC series, the individual is the unit of analysis and the estimates refer to inequality among all individuals (including children); in the ONS-ETB series, the unit of analysis is the household and the estimates refer to inequality among all households. To facilitate comparisons across series, we have also applied the ONS-ETB definitions to the SPI-HBAI data: this leads to the HBAI-SPI(hh) series of Gini coefficients.

To these series, we add two other series derived from HBAI-SPI data. One trims the top 5\%, and the second trims the top 5\% and the bottom 5\% as per Belfield et al. (2017). We discuss these two series in Section VI.

$<$ Figure 3 about here $>$

There is a striking difference between the inequality levels recorded by the HBAI-SPI series and the two ONS series. Inequality levels according to the HBAI-SPI series are around two percentage points higher each year, and there is a bigger gap between the HBAI-SPI(hh) and ONS-ETB series. As we show in Figure 4 (discussed below), the SPI adjustment is an important contributor to these systematic differences. The SPI adjustment also helps explain the differences in trends over time across series, though the smaller sample sizes underlying the ONS-ETB and ONS-EUSILC series also contributes to their greater volatility.

\footnotetext{
${ }^{13}$ For extensive discussion of estimates of top income shares from different series, see Burkhauser et al. (2016).
} 
To look at the effect of the SPI adjustment on income inequality estimates in more detail, we focus on the HBAI-SPI series and the period 1994/95-2014/15. The effects of the SPI adjustment on the Gini coefficient for household equivalised net income among all individuals are presented in Figure $4 .^{14}$

$<$ Figure 4 near here $>$

The SPI-adjusted net income series (HBAI-SPI; solid black line) shows higher inequality than the unadjusted HBAI series (HBAI; solid grey line) in 15 of the 21 years. Only in 2000/01 and 2008/09 is the Gini coefficient of the adjusted series appreciably lower than the Gini coefficient of the unadjusted series. The effects of the recalibrations to the grossing-up factors can be seen by comparing the HBAI series with the 'HBAI (HBAI-SPI weights)' series (dashed grey line).

This comparison shows that changes to the weights systematically increase the Gini coefficient in all years other than 1994/95, 1996/97, 1997/98, and 2000/01, where the effect is negligible. Moving from the HBAI (HBAI-SPI weights) to the HBAI-SPI series shows the effects of the adjustments to the income values. These adjustments further increase the Gini coefficient in 11 of the 21 years, but also substantially reduce the Gini coefficient in six of the years.

The net effect of the SPI adjustment is to substantially reduce year to year volatility in estimates of the Gini coefficient. In addition, the HBAI-SPI series leads one to conclude that inequality increased slightly over the $1994 / 95$ to $2014 / 15$ period, rather than decreased, which is what the unadjusted HBAI series shows. In particular, the decline in the Gini coefficient after $2009 / 10$ is markedly smaller for the adjusted series. ${ }^{15}$

The SPI adjustment reduces the volatility of other measures of overall inequality as well. The mean logarithmic deviation, Theil index, and the half the squared coefficient of variation (HSCV), each commonly used in income distribution analysis, also exhibit considerably less volatility for the adjusted series. (See Appendix Figures A2-A4.) The HSCV is particularly sensitive to the presence of outliers and its volatility is greatly reduced by the SPI adjustment for the years in which the HBAI contains one or two extreme outliers, such as in 2001/02, 2005/06 and 2008/09.

\footnotetext{
${ }^{14}$ See Appendix Figure A1 for the corresponding series based on the distribution of individual personal gross income. The patterns are very similar.

${ }^{15}$ While the Great Recession provides one explanation for the sharp decline in inequality between 2009/10 and $2010 / 11$, the decline is also likely to be due to the forestalling and reverse forestalling issues cited earlier.
} 


\section{Discussion and conclusions}

The SPI adjustment has two stated goals: to improve the quality of data on very high incomes; and to reduce spurious volatility. With respect to the latter goal, Matejic (n. d.) discusses the effect of the SPI adjustment on volatility for the period between 2002/03 and 2009/10. He reports that once five extreme outlier values for individual-level net income are excluded (over the entire period), there is little difference between the top three values from year to year. Matejic's conclusion is that 'there is not that much of [a] difference between the maximum incomes over time, and thus any mean and other statistics would not be very volatile' (n. d.: 6). This in turn implies that the current SPI adjustment does much more than is necessary to reduce top income volatility. The findings discussed in the previous section corroborate this assessment.

Systematic trimming of the income distribution is a commonly-used approach to data quality. For example, Brewer and Wren-Lewis state that they 'trim the top and bottom $1 \%$ of households in each year; in doing so, we remove all of the very high and very low income households whose reported incomes are adjusted by government statisticians before the micro data are made available' (2016: 297). ${ }^{16}$ An even more radical approach is taken by Belfield et al. (2017) who trim the top 5\% and the bottom 5\%. Trimming removes most high-leverage outlier observations that account for potentially spurious volatility in inequality trends. But at the same time, a very important range of the income distribution - the very top, which is where most changes have been occurring over the last two decades in the UK - is totally ignored. Figure 3 shows that Belfield et al.'s (2017) estimates of inequality for the middle 90 per cent of the distribution are approximately 10 percentage points lower than the HBAI-SPI estimates of overall inequality, and variations over time are flattened out. The series without bottom trimming shows that is the trimming of top incomes that drives these effects. Put differently, the trimmed series for the income distribution are very different from the series for the overall income distribution.

Belfield et al. (2017: 162) raise an additional point. If one's purpose is to undertake decompositions by income source, then data including SPI-adjusted incomes are problematic because the cell-mean imputations refer to an income aggregate (e.g. gross or net income) and not its components. Radical trimming removes the adjusted observations and makes

\footnotetext{
${ }^{16}$ Trimming the top $1 \%$ would not necessarily remove all the observations subject to the SPI adjustment, as we show earlier.
} 
decomposition analysis feasible. Observe that the SPI does not have sufficiently detailed information about income components to take a more disaggregated approach to SPI-type adjustments.

However, decomposition is a separate issue from deriving better estimates of overall inequality levels and trends in the population as a whole. National statistical agencies can pursue the latter goal for their headline distributional series without compromising other types of analysis by researchers, as long as access to the detailed survey unit record data about income components is maintained (as it is in the UK and many other countries).

While the current SPI adjustment does more than is required to reduce volatility, we have shown that it falls short of producing an income series in line with SPI data for top incomes. Thus, we believe that there are prima facie grounds for reconsidering the design of the SPI adjustment.

One modification we suggest is to omit the stratification in the adjustment (currently based on distinctions between pensioners and non-pensioners and between Great Britain and Northern Ireland residents). Our view is that the main decision regarding the SPI adjustment concerns the number of high income individuals that should be subject to the adjustment. The discussion around this decision is much clearer if it is framed simply as a decision about the number of top income groups to be adjusted. For example, do we want all the top $1 / 2$ per cent individual incomes to be SPI adjusted? Or only the top 0.1 per cent? Or the top 5 per cent or 10 per cent? Given the stated goals of the SPI adjustment, there is no obvious reason why these thresholds should differ for Great Britain and Northern Ireland or between pensioners and non-pensioners. As we have explained, the stratification by residence appears simply to reflect a change in FRS survey coverage. Households Below Average Income and The Pensioner Income Series are based on a common HBAI methodology definitions; it is unclear why they should have separate top income adjustments.

Stratification might be motivated by the desire to examine distributions for subgroups such as devolved administrative regions (but residence in Scotland and Wales is not used for stratification). In any case, this is not a stated purpose of the SPI adjustment. One could also conceive of other population subgroups of at least as great an interest such as men and women, or different age groups (personal characteristics also identifiable in the SPI data).

In addition to omitting stratification, more fundamental changes to the adjustment method could be made to better utilise the SPI data to improve the capture of top incomes in the HBAI data. First, systematic comparison of the SPI and HBAI income distributions could ascertain how far down the HBAI income distribution the SPI data can be used to improve 
measurement of high incomes. Our earlier findings, in particular from Figure 1, suggest that SPI adjustment to the incomes of individuals in the top 5 per cent is likely to be appropriate to estimates of the Gini coefficient and other inequality indices (see also Jenkins 2017). By contrast, any adjustment to members of the top 10 per cent to 5 per cent group is unlikely to have any significant impact because the differences between survey and tax data are limited for this group.

Second, when adjusting the HBAI data, information about the distribution of income among high income individuals could be preserved by adopting a more granular approach than simply assigning every individual over a particular threshold the same income (a mean). One possible approach, which we have implemented in Burkhauser et al. (2016), is to identify the 0.1 percentile group of each individual in the HBAI (personal gross) income distribution and replace their income with the mean of individuals in the same 0.1 percentile group of the SPI income distribution. ${ }^{17}$ (In principle, even greater granularity is possible.) Burkhauser et al. (2016) focus on the case in which adjustments are made to the top 5 per cent, but also consider variants in which adjustments made to the incomes of the top 10, 4, 3, 2,1 , or $1 / 2$ per cent. They find that their inequality estimates are insensitive to variants that include at least the top 2 per cent, implying adjustments are required further down the distribution than the SPI adjustment's $1 / 2$ per cent.

Third, and separately from the survey under-coverage issue, we have shown how the lags in availability of SPI data mean that projections are required in order to implement the SPI adjustment to HBAI incomes and that there appears to be systematic undershooting of income totals for very rich groups. This suggests that the principles underlying the projection method could be fruitfully revisited. Where the focus of attention should be is difficult to say because there is no detailed documentation, a situation that could be improved. We also wonder about the possibilities for making SPI data available more quickly. Recent process reviews enabled the DWP to bring forward the publication of FRS 2015/16 by more than three months compared to FRS 2014/15 (Department for Work and Pensions 2017: 24). Timeliness of the release of the Households Below Average Income report, based on the HBAI-SPI data, has also improved substantially in recent years. Improving the timeliness of the SPI data (and making more years of unit record data available) is contingent on resources being made available within HMRC.

\footnotetext{
${ }^{17}$ Burkhauser et al. (2016) were unable to produce net income variables for the adjusted cases because they did not have access to the DWP tax-benefit calculator. This constraint is not faced by the DWP.
} 
We acknowledge that there are some fundamental limitations to the SPI adjustment or variants of it that arise because it is based on an individual level data set (the SPI).

Individuals from the same household cannot be linked to each other. This matters because we are most concerned from a welfare perspective in distributions of household income. As a referee put it, an increase over time in the correlation in the earnings of partners will tend to increase the inequality of household income in a way that cannot be 'corrected' for using the SPI.

We also acknowledge that there are other approaches to improving estimates of overall income inequality that also use tax data to improve coverage of top incomes. A leading example is the method of Atkinson (2007) and Alvaredo (2011), recently applied to the UK by Jenkins (2017). Whereas the SPI adjustment and the Burkhauser et al. (2016) approach use the tax data to modify the survey data and then calculate overall inequality from the adjusted and combined data, the Atkinson-Alvaredo approach combines inequality estimates in each of the two data sources separately and then combines them. Total inequality is calculated as the sum of inequality among the poorest $p$ per cent (derived from the survey) + inequality among the richest $(100-p)$ per cent (derived from the tax data) + inequality between the rich and poor groups (which depends on their mean incomes and $p$ ). Jenkins (2017) demonstrates that the Burkhauser et al. and Atkinson-Alvaredo approaches provide similar estimates of income inequality trends in the UK between the mid-1990s and the late2000 s. Both of the two approaches point to a larger increase in inequality in the early-2000s than does the HBAI-SPI series. ${ }^{18}$ Both approaches take better account of under-coverage of top incomes, including of the top $0.1 \%$ (cf. Figure $2(b)$ ).

The UK's experience suggests some lessons concerning whether other countries could implement variants on SPI adjustment methodologies to improve their estimates of income inequality levels and trends. What is needed is access to both suitable income tax record data and to high quality household survey data with detailed information about income components. What is available varies across countries and, indeed, the extent and nature of under-coverage of top incomes in household surveys may vary across countries, necessitating differences in approach.

For Australia, Burkhauser, Hahn, and Wilkins (2016) demonstrate that there is potential to reconcile and combine survey and tax data in an SPI adjustment-type way, but the ability for the combined data to track the top income share series in Australian Tax Office tax

\footnotetext{
${ }^{18}$ Another potential approach to deal with under-coverage of top incomes, employed by Alfons et al. (2013) and Ruiz and Woloszko (2015), is based on fitting a Pareto distribution to top incomes in the survey data (making no use of tax data). Jenkins (2017) explains why this approach is unsatisfactory.
} 
table benchmarks is currently constrained by aggressive top-coding and perturbation of observations in the publicly-released tax unit record data. Bach et al. (2009) show that it is possible to reconcile and combine survey and tax data in Germany, and thereby provide a better picture of the entire income distribution from bottom to top, as they phrase it. By contrast with the SPI adjustment, and reflecting the nature of the data available, their approach uses statistical matching across data sets rather than cell mean imputations. For the USA, the work of Larrimore et al. (2016) shows that it is possible to reconcile and combine survey data from the Current Population Survey with IRS SOI personal tax record data. Their analysis includes definitions of income extended to also include capital gains. Larrimore et al. (2017) show that in the USA it is possible to link individuals from the same household in the tax data combining information across the universe of federal income tax data collected by the IRS.

These illustrations underline our point that the scope for improving estimates of inequality levels and trends by taking better account of top incomes using tax data is contingent on the nature of the data available (and the nature of survey under-coverage). The more important lesson is that improvements per se are possible and they could be implemented in many countries by the guardians of national statistical series on income distribution with appropriate coordination between the agency in charge of the survey and the national tax office.

\section{References}

Alfons, A., Templ, M. and Filzmoser, P. (2013), 'Robust estimation of economic indicators from survey samples based on Pareto tail modelling, Journal of the Royal Statistical Society, Series $C$, vol. 62, pp. 271-286.

Atkinson A. B., Piketty, T., and Saez, E. (2011), 'Top incomes in the long run of history', Journal of Economic Literature, vol. 49, pp. 3-71.

Bach, S., Corneo, G., and Steiner, V. (2009), 'From bottom to top. The entire income distribution in Germany, 1992-2003', Review of Income and Wealth, vol. 55, pp. $303-330$.

Bee, C. A., Gathright, G. M. R., and Meyer, B. D. (2015), 'Bias in unit non-response in the measurement of income in household surveys', unpublished paper (4 August 2015), 
Chicago IL: Harris School, University of Chicago.

https://harris.uchicago.edu/files/jsm2015 bgm unit non-response in cps.pdf

Belfield, C., Cribb, J., Hood, A., and Joyce, R. (2016), Living Standards, Poverty and Inequality in the UK: 2016, Report 117, London: Institute for Fiscal Studies. http://www.ifs.org.uk/uploads/publications/comms/R117.pdf

Belfield, C. Blundell, R., Cribb, J., Hood, A., and Joyce, R. (2017), 'Two decades of income inequality in Britain: the role of wages, household earnings and redistribution', Economica, vol. 84, pp. 157-179.

Brewer, M., Etheridge, B., and O’Dea, C. (2015), 'Why are households that report the lowest incomes so well-off?', http://repository.essex.ac.uk/14894/. Economic Journal, forthcoming.

Brewer, M. and Wren-Lewis, L. (2016), 'Accounting for changes in income inequality: decomposition analyses for the UK, 1978-2008', Oxford Bulletin of Economics and Statistics, vol. 78, pp. 289-322.

Burkhauser, R. V., Feng, S., Jenkins, S. P. and Larrimore, J. (2012), 'Recent trends in top income shares in the USA: reconciling estimates from March CPS and IRS tax return data', Review of Economics and Statistics, vol. 94, pp. 371-388.

Burkhauser, R. V., Hahn, M., and Wilkins, R. (2016), 'Top incomes and inequality in Australia: reconciling recent estimates from household survey and tax return data', unpublished paper, Melbourne: Melbourne Institute for Applied Economic and Social Research.

Burkhauser, R. V., Hérault, N., Jenkins, S. P., and Wilkins, R. (2016), 'Has UK income inequality increased recently? Answers from reconciled and combined household survey and tax return data', Working Paper 21991, Cambridge, MA: National Bureau of Economic Research. Revised version (August 2016) available from http://www.iariw.org/dresden/wilkins.pdf

Department for Work and Pensions (2004), Review of Households Below Average Income and the Pensioners' Incomes Series, National Statistics Quality Review Series, Report No. 28. London: Department for Work and Pensions.

Department for Work and Pensions (2011), Households Below Average Income An Analysis of the Income Distribution 1994/95 - 2009/10, London: Department for Work and Pensions. 
Department for Work and Pensions (2014a), Households Below Average Income. An Analysis of the Income Distribution 1994/95 - 2012/13, London: Department for Work and Pensions.

Department for Work and Pensions (2014b), The Pensioners' Incomes Series. United Kingdom, 2012/13, London: Department for Work and Pensions.

Department for Work and Pensions (2015), Households Below Average Income. Quality and Methodology Information Report - 2013/14, London: Department for Work and Pensions.

Department for Work and Pensions (2016a), Family Resources Survey. United Kingdom, 2014/15, London: Department for Work and Pensions.

Department for Work and Pensions (2016b), Households Below Average Income. Quality and Methodology Information Report - 2014/15, London: Department for Work and Pensions.

Department for Work and Pensions (2017), Family Resources Survey. United Kingdom, 2015/16, London: Department for Work and Pensions.

Gray, C. (2007), 'SPI documentation - how to decide on thresholds', unpublished paper, London: Department for Work and Pensions.

HM Revenue and Customs (2012). The Exchequer Effect of the 50 per cent Additional Rate of Income Tax. London: HMRC.

http://webarchive.nationalarchives.gov.uk/20140206144454/http://www.hmrc.gov.uk/bu dget2012/excheq-income-tax-2042.pdf

HM Revenue and Customs (2016a), Personal Incomes Statistics 2013-14. Tables 3.1-3.11. London: HMRC. https://www.gov.uk/government/uploads/system/uploads/attachment data/file/503472 /SPI_National_Statistics_T3_1_to_T3_11.pdf

HM Revenue and Customs (2016b), UK Income Tax Liabilities Statistics: 2013-14 Survey of Personal Incomes, with projections to 2016-17. London: HMRC.

https://www.gov.uk/government/statistics/income-tax-liabilities-statistics-tax-year2013-to-2014-to-tax-year-2016-to-2017

Jenkins, S. P. (2017), 'Pareto models, top incomes, and recent trends in UK income inequality', Economica, vol. 84, pp. 261-289.

Larrimore, J., Burkhauser, R. V., Auten, G., and Armour, P. (2016), 'Recent trends in U.S. top income shares in tax record data using more comprehensive measures of income 
including accrued capital gains', NBER Working Paper 23007, Cambridge MA: National Bureau of Economic Research.

Larrimore, J., Mortenson, J., and Splinter, D. (2017), 'Household incomes in tax data: using addresses to move from tax unit to household income distributions', Finance and Economics Discussion Series 2017-002, Washington: Board of Governors of the Federal Reserve System.

https:/www.federalreserve.gov/econresdata/feds/2017/files/2017002pap.pdf

Matejic, P. (n. d.), 'The Survey of Personal Incomes adjustment to HBAI incomes', unpublished paper, London: Department for Work and Pensions.

Office for National Statistics (2016), 'The effects of taxes and benefits on household incomes: financial year ending 2015', London: ONS.

http://www.ons.gov.uk/peoplepopulationandcommunity/personalandhouseholdfinance s/incomeandwealth/bulletins/theeffectsoftaxesandbenefitsonhouseholdincome/financi alyearending 2015

Ruiz, N. and N. Woloszko (2015), 'What do household surveys suggest about the top 1\% incomes and inequality in OECD countries?', OECD Economics Department Working Paper 1265, Paris: OECD Publishing.

Seely, A. (2014), 'Income tax: the additional 50p rate', Standard Note SN 249, London: House of Commons Library. http://researchbriefings.parliament.uk/ResearchBriefing/Summary/SN00249\#fullreport 
TABLE 1

Comparison of SPI projections and SPI outturns for 'very rich' individuals, 2010/11, by stratification group

\begin{tabular}{|c|c|c|c|c|c|c|c|}
\hline \multirow[t]{2}{*}{ Stratification group } & \multicolumn{2}{|c|}{ Mean gross income (£) } & \multicolumn{2}{|c|}{$\begin{array}{l}\text { Weighted number of } \\
\text { individuals }\end{array}$} & \multicolumn{3}{|c|}{ Total gross income ( $£$ billion) } \\
\hline & Projection & Outturn & Projection & Outturn & Projection & Outturn & $\begin{array}{c}\text { Difference } \\
(\%)\end{array}$ \\
\hline GB non-pensioner & 527,635 & $\begin{array}{r}492,173 \\
(4,792)\end{array}$ & 112,998 & $\begin{array}{r}136,186 \\
(232)\end{array}$ & 59.6 & $\begin{array}{l}67.0 \\
(0.6)\end{array}$ & -11.0 \\
\hline NI non-pensioner & 250,885 & $\begin{array}{r}239,725 \\
(11,020)\end{array}$ & 3,301 & $\begin{array}{r}2,855 \\
(58)\end{array}$ & 0.8 & $\begin{array}{r}0.7 \\
(0.0)\end{array}$ & 21.0 \\
\hline GB pensioner & 134,228 & $\begin{array}{r}123,324 \\
(1,363)\end{array}$ & 132,797 & $\begin{array}{r}135,473 \\
(789)\end{array}$ & 17.8 & $\begin{array}{l}16.7 \\
(0.2)\end{array}$ & 6.7 \\
\hline NI pensioner & 114,460 & $\begin{array}{r}118,317 \\
(12,518)\end{array}$ & 3,400 & $\begin{array}{l}3,476 \\
(109)\end{array}$ & 0.4 & $\begin{array}{r}0.4 \\
(0.0)\end{array}$ & -5.4 \\
\hline Total (all groups) & 311,546 & $\begin{array}{r}305,154 \\
(2,815) \\
\end{array}$ & 252,496 & $\begin{array}{r}277,991 \\
(913) \\
\end{array}$ & 78.7 & $\begin{array}{r}84.8 \\
(0.7) \\
\end{array}$ & -7.3 \\
\hline
\end{tabular}

Notes. Projections are taken from HBAI-SPI data. Outturns are taken from SPI outturn data. See main text for further discussion. Incomes are in 2010/11 prices. GB: Great Britain (England, Wales, Scotland). NI: Northern Ireland. Estimated standard errors in parentheses.

Sources: authors' calculations from HBAI-SPI and SPI data. 
TABLE 2

Impact of SPI adjustments to incomes and grossing factors on population shares and mean gross income, individuals subject to the SPI adjustment, 1994/95-2014/15

\begin{tabular}{|c|c|c|c|c|c|c|}
\hline \multirow[b]{2}{*}{$\begin{array}{l}\text { Financial } \\
\text { year }\end{array}$} & \multicolumn{2}{|c|}{$\begin{array}{c}\text { Population share of 'very rich' } \\
\text { individuals subject to the SPI } \\
\text { adjustment (\%) }\end{array}$} & \multicolumn{4}{|c|}{$\begin{array}{l}\text { Mean individual gross income of the 'very rich' (pounds } \\
\text { per week, 2014/15 prices) }\end{array}$} \\
\hline & FRS weights & $\begin{array}{l}\text { HBAI-SPI } \\
\text { weights }\end{array}$ & $\begin{array}{l}\text { HBAI } \\
\text { incomes and } \\
\text { FRS weights } \\
\text { (3) }\end{array}$ & $\begin{array}{c}\text { HBAI } \\
\text { incomes and } \\
\text { HBAI-SPI } \\
\text { weights } \\
\text { (4) }\end{array}$ & $\begin{array}{l}\text { HBAI-SPI } \\
\text { incomes } \\
\text { and FRS } \\
\text { weights } \\
(5)\end{array}$ & $\begin{array}{l}\text { HBAI-SPI } \\
\text { incomes } \\
\text { and } \\
\text { weights } \\
(6)\end{array}$ \\
\hline 1994/95 & 0.17 & 0.18 & 4,852 & 4,201 & 7,452 & 6,156 \\
\hline 1995/96 & 0.09 & 0.12 & 6,142 & 6,068 & 9,198 & 9,117 \\
\hline 1996/97 & 0.13 & 0.13 & 6,416 & 6,330 & 8,921 & 8,787 \\
\hline 1997/98 & 0.23 & 0.26 & 4,937 & 4,420 & 8,331 & 7,179 \\
\hline 1998/99 & 0.11 & 0.14 & 8,481 & 8,476 & 10,319 & 10,531 \\
\hline 1999/00 & 0.13 & 0.20 & 6,534 & 6,525 & 9,256 & 9,127 \\
\hline 2000/01 & 0.20 & 0.24 & 11,176 & 9,643 & 11,049 & 9,825 \\
\hline 2001/02 & 0.21 & 0.27 & 9,977 & 11,211 & 8,637 & 9,265 \\
\hline $2002 / 03$ & 0.19 & 0.27 & 6,043 & 5,975 & 9,443 & 9,343 \\
\hline 2003/04 & 0.22 & 0.28 & 5,949 & 6,336 & 7,638 & 8,157 \\
\hline $2004 / 05$ & 0.25 & 0.32 & 5,186 & 5,476 & 7,575 & 7,955 \\
\hline 2005/06 & 0.23 & 0.34 & 9,431 & 9,787 & 7,590 & 7,618 \\
\hline 2006/07 & 0.28 & 0.42 & 5,821 & 5,515 & 7,628 & 7,130 \\
\hline 2007/08 & 0.31 & 0.51 & 5,152 & 4,797 & 7,722 & 7,130 \\
\hline 2008/09 & 0.35 & 0.50 & 8,022 & 8,342 & 7,126 & 7,475 \\
\hline 2009/10 & 0.32 & 0.50 & 5,959 & 7,106 & 6,818 & 7,904 \\
\hline 2010/11 & 0.36 & 0.50 & 5,887 & 5,250 & 7,271 & 6,475 \\
\hline 2011/12 & 0.29 & 0.49 & 4,804 & 4,813 & 7,020 & 6,976 \\
\hline $2012 / 13$ & 0.29 & 0.49 & 4,592 & 4,831 & 5,778 & 6,242 \\
\hline 2013/14 & 0.26 & 0.50 & 8,628 & 12,338 & 5,905 & 7,805 \\
\hline 2014/15 & 0.34 & 0.50 & 4,521 & 5,228 & 6,272 & 7,487 \\
\hline
\end{tabular}

Notes: Northern Ireland is included only from 2002/03 onwards.

Source: Authors' calculations from FRS and HBAI data. 
FIGURE 1

(a) Ratio of individual gross income total (HBAI) to individual gross income total (SPI), by income group

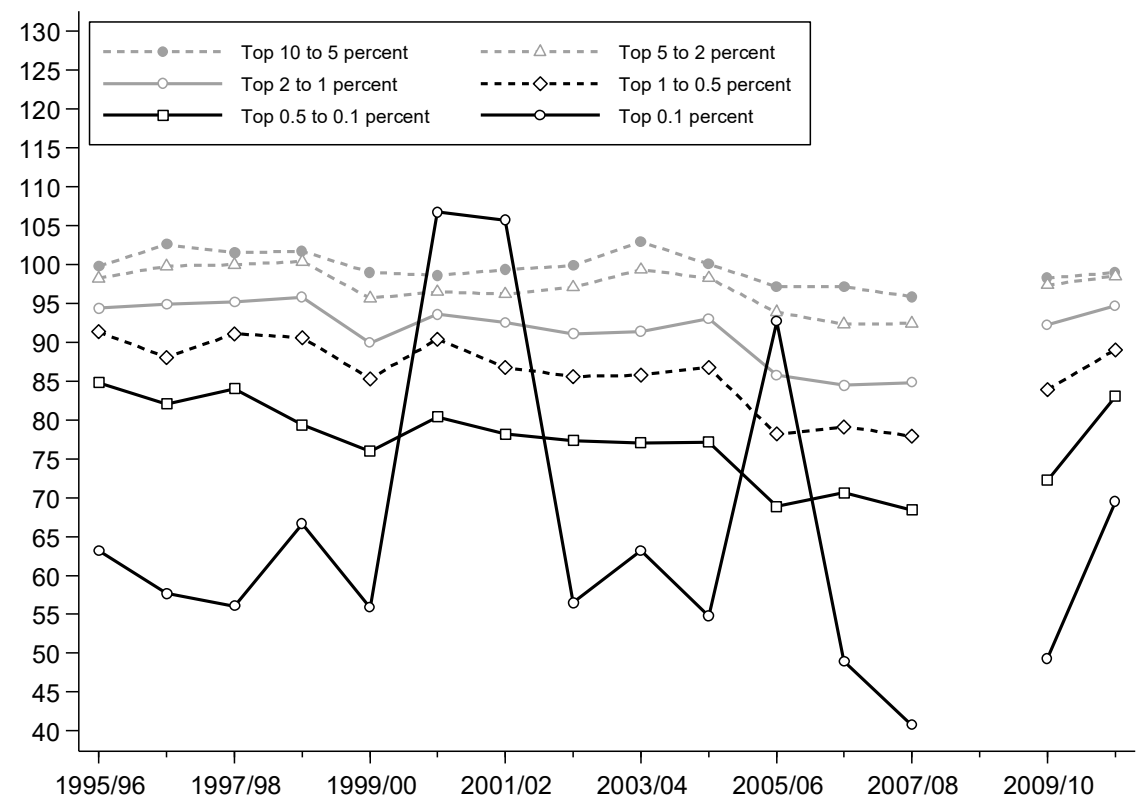

(b) Ratio of individual gross income total (HBAI-SPI) to individual gross income total (SPI), by income group

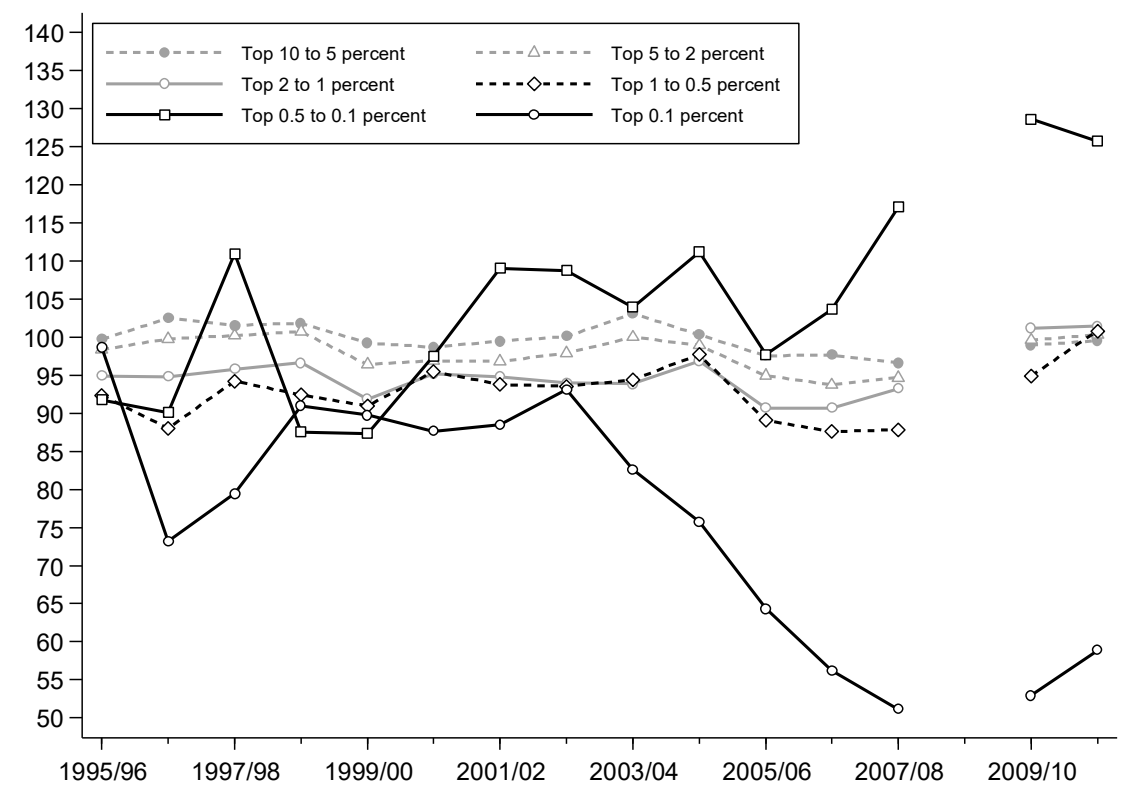

Notes: Income groups are constructed based on HBAI adult gross income and on ONS controls for total adult population. Northern Ireland is included in the survey-based series only from 2002/03 onwards. The data series are explained in Section II.

Source: Authors' calculations based on FRS, HBAI and SPI data.

(Stata graph Incgroup_Histo_SPIratios1b \& Incgroup_Histo_SPIratios2) 
FIGURE 2

Density estimates of the upper tail of the distribution of individual gross income, 2010/11, $H B A I$ and $H B A I-S P I$

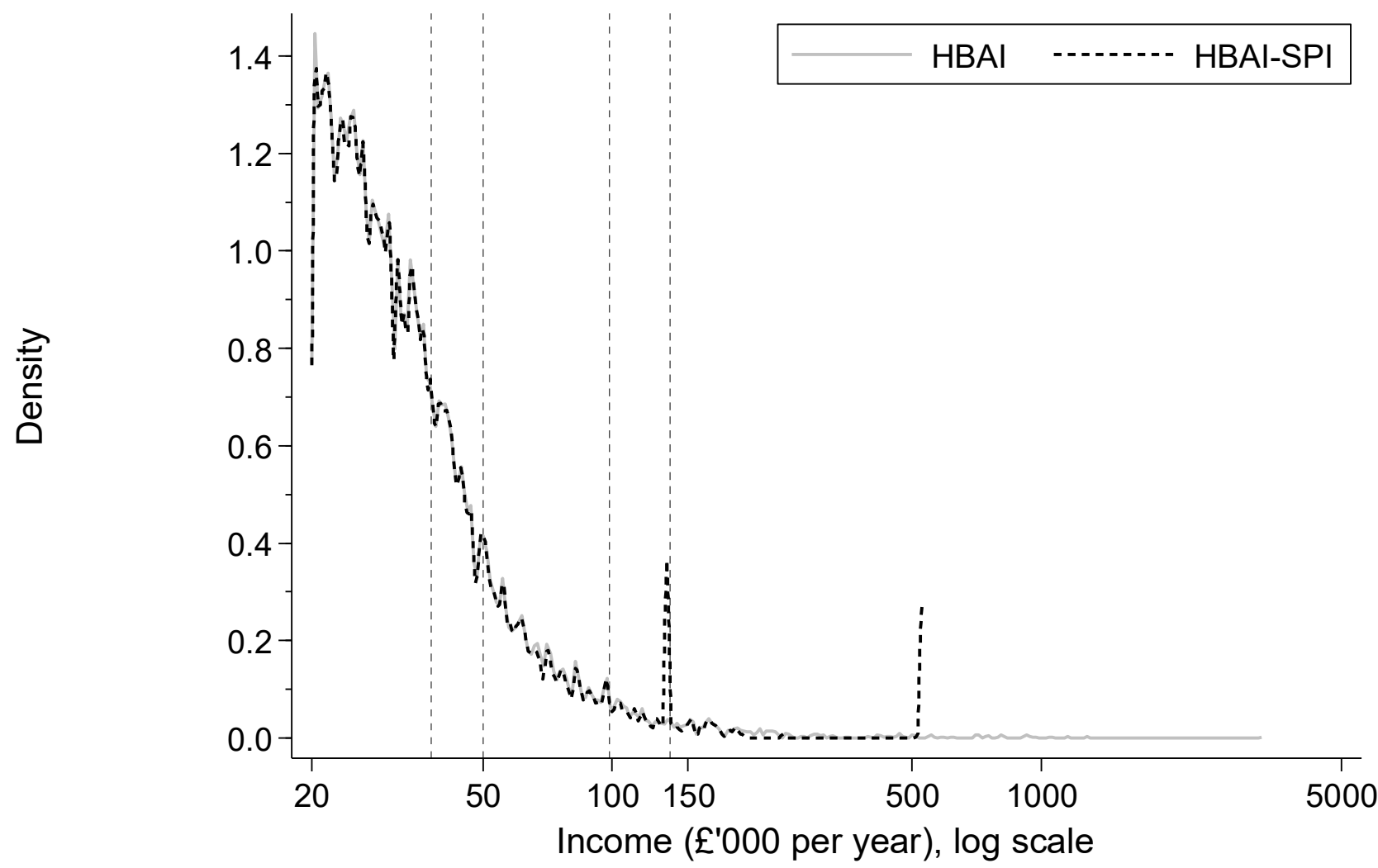

Notes: Kernel density estimates were calculated for the distribution of log income using observations with income) greater than $£ 20,000$ per year, using an Epanechnikov kernel and bandwidth of 0.008 . The dashed vertical lines show the 90th, 95th, 99th, and 99.5th percentiles in the HBAI data. The distributions refer to individual gross income among individuals aged $15+$.

Source: Authors' calculations based on FRS and HBAI.

(Stata graph overlap10_kdensity_noSPI-SPI_2010) 
FIGURE 3

UK income inequality (Gini coefficient), 2005/06-2014/15, by series

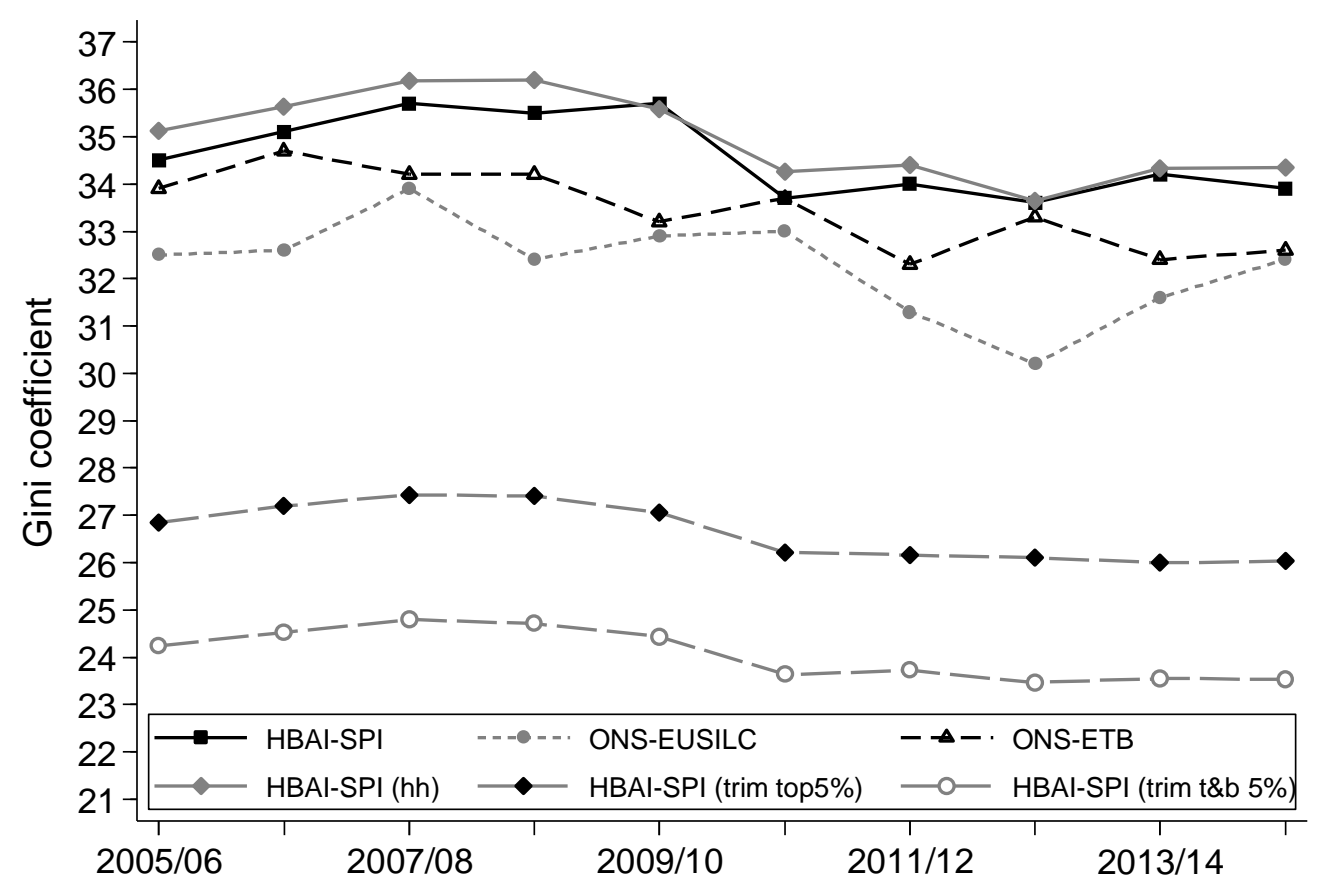

Notes. The series are explained in the main text. Only the HBAI-SPI and HBAI-SPI(hh) series incorporate SPI adjustments. HBAI-SPI (trim top5\%) is the HBAI-SPI series with the top 5 per cent of individuals trimmed. HBAI-SPI (trim t\&b 5\%) is the HBAI-SPI series with the top 5 per cent of individuals trimmed.

Sources. HBAI-SPI: spreadsheet accompanying Belfield et al. (2016), which is the same series as reported in DWP (2016a). HBAI-SPI (hh): authors' calculations based on HBAI data. ONSETB: ONS (2016). EU-SILC: series ilc_di12, downloaded from Eurostat’s online database, 23 August 2016.

(Stata graph: gini_variant_02_01) 
FIGURE 4

Gini coefficients calculated from income distributions with and without SPI adjustments

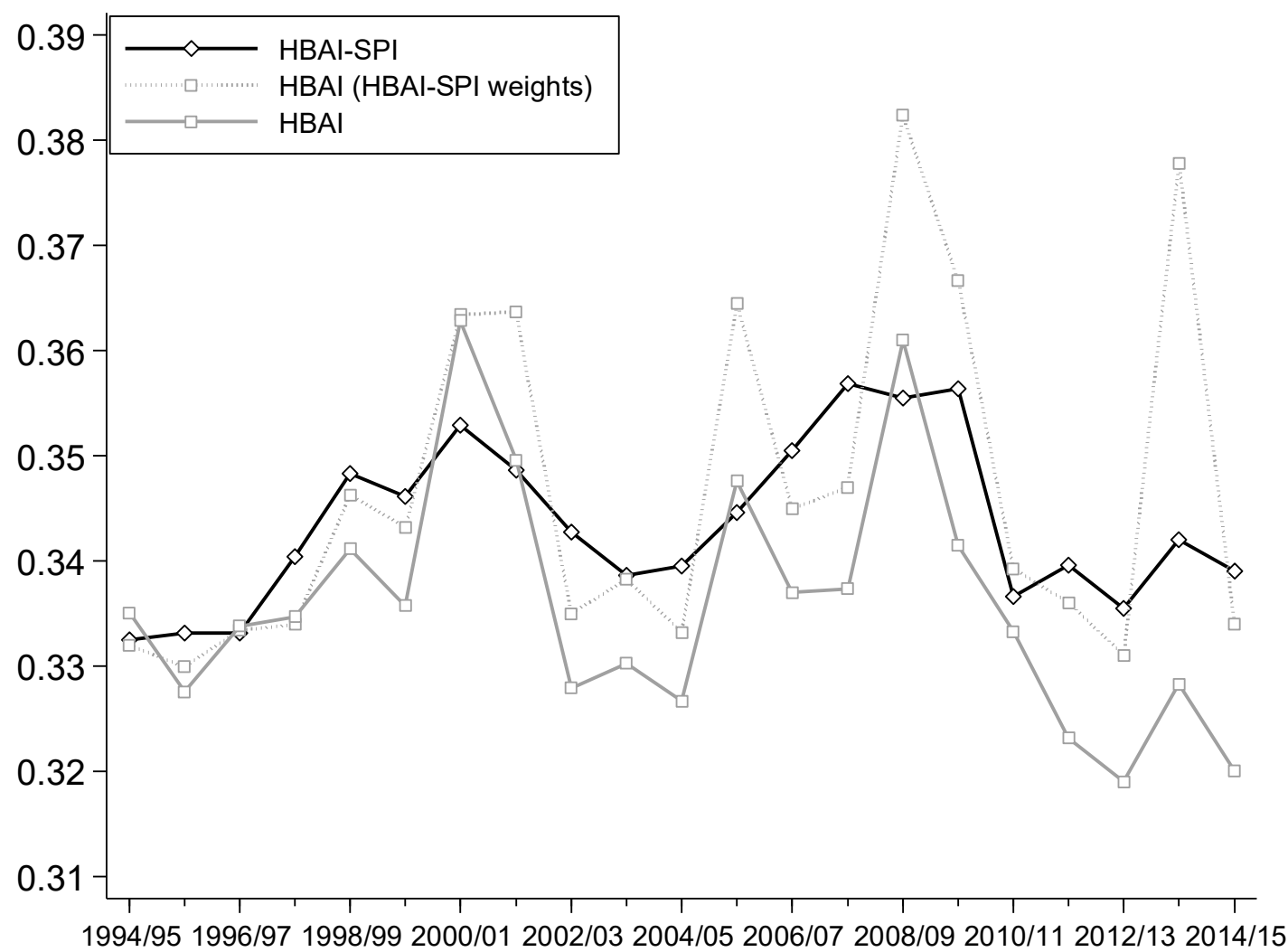

Notes: In each series, the distribution is of equivalised household net income among all individuals. Northern Ireland is included only from 2002/03 onwards. The income definition and series acronyms are explained in Section II.

Source: Authors' calculations based on FRS, HBAI and SPI data.

(Stata graph Ginilg) 


\section{APPENDIX \\ (ONLINE SUPPLEMENTARY MATERIAL)}

to accompany

Survey under-coverage of top incomes and estimation of inequality: what is the role of the UK's SPI adjustment?

Richard V. Burkhauser

Cornell University and University of Melbourne

Nicolas Hérault

University of Melbourne

Stephen P. Jenkins

London School of Economics

Roger Wilkins

University of Melbourne 
TABLE A1

Gross income thresholds for eligibility for the SPI adjustments (pounds per year, nominal)

\begin{tabular}{lcrcc}
\hline Fiscal year & \multicolumn{2}{c}{ Great Britain } & \multicolumn{2}{c}{ Northern Ireland } \\
& Non-pensioners & Pensioners & Non-pensioners & Pensioners \\
\hline $1994 / 95$ & 100,000 & 50,000 & - & - \\
$1995 / 96$ & 100,000 & 100,000 & - & - \\
$1996 / 97$ & 100,000 & 100,000 & - & - \\
$1997 / 98$ & 100,000 & 50,000 & - & - \\
$1998 / 99$ & 150,000 & 75,000 & - & - \\
$1999 / 00$ & 150,000 & 60,000 & - & - \\
$2000 / 01$ & 150,000 & 60,000 & - & - \\
$2001 / 02$ & 150,000 & 60,000 & - & - \\
$2002 / 03$ & 150,000 & 60,000 & 150,000 & 60,000 \\
$2003 / 04$ & 150,000 & 60,000 & 150,000 & 60,000 \\
$2004 / 05$ & 150,000 & 60,000 & 150,000 & 60,000 \\
$2005 / 06$ & 150,000 & 60,000 & 150,000 & 60,000 \\
$2006 / 07$ & 150,000 & 60,000 & 150,000 & 60,000 \\
$2007 / 08$ & 150,000 & 60,000 & 150,000 & 60,000 \\
$2008 / 09$ & 150,000 & 60,000 & 100,000 & 60,000 \\
$2009 / 10$ & 256,136 & 60,347 & 167,133 & 55,253 \\
$2010 / 11$ & 202,952 & 65,321 & 141,044 & 57,091 \\
$2011 / 12$ & 237,136 & 68,601 & 131,732 & 59,731 \\
$2012 / 13$ & 236,694 & 73,631 & 131,166 & 60,088 \\
$2013 / 14$ & 259,552 & 76,347 & 135,647 & 63,895 \\
$2014 / 15$ & NA & NA & NA & NA \\
\hline & & & & \\
\hline
\end{tabular}

Notes. In years prior to $2009 / 10$, the thresholds are based on net rather than gross income for non-pensioners. For all other years and groups, the thresholds are based on gross income. The Family Resources Survey did not include Northern Ireland before 2002/03. NA: Not available.

Source: Department for Work and Pensions (2015) for 2013/14 and previous HBAI reports for earlier years. 
TABLE A2

Weighted and unweighted numbers of individuals in HBAI data, by SPI-adjustment eligibility (all individuals aged 15 years or more)

\begin{tabular}{cccccc}
\hline \multirow{2}{*}{$\begin{array}{c}\text { Fiscal } \\
\text { year }\end{array}$} & Weighted & Unweighted & Weighted & Unweighted & $\begin{array}{c}\text { Total } \\
\text { population }\end{array}$ \\
\cline { 2 - 5 } $1994 / 95$ & $44,384,604$ & 48,848 & 77,999 & 77 & $44,462,603$ \\
$1995 / 96$ & $44,508,236$ & 48,524 & 52,004 & 45 & $44,560,241$ \\
$1996 / 97$ & $44,698,884$ & 47,271 & 60,002 & 61 & $44,758,887$ \\
$1997 / 98$ & $44,795,192$ & 43,767 & 116,447 & 98 & $44,911,638$ \\
$1998 / 99$ & $45,010,976$ & 42,414 & 64,001 & 46 & $45,074,975$ \\
$1999 / 00$ & $45,130,540$ & 46,138 & 89,001 & 56 & $45,219,542$ \\
$2000 / 01$ & $45,374,004$ & 43,803 & 109,000 & 84 & $45,483,004$ \\
$2001 / 02$ & $45,546,944$ & 46,723 & 125,008 & 99 & $45,671,954$ \\
$2002 / 03$ & $47,291,028$ & 52,950 & 127,311 & 93 & $47,418,339$ \\
$2003 / 04$ & $47,502,560$ & 52,971 & 133,610 & 115 & $47,636,171$ \\
$2004 / 05$ & $47,813,188$ & 51,390 & 152,601 & 127 & $47,965,790$ \\
$2005 / 06$ & $48,366,940$ & 51,569 & 166,603 & 126 & $48,533,542$ \\
$2006 / 07$ & $48,776,460$ & 47,263 & 203,401 & 131 & $48,979,862$ \\
$2007 / 08$ & $49,282,236$ & 45,537 & 254,401 & 136 & $49,536,637$ \\
$2008 / 09$ & $49,730,852$ & 45,611 & 252,002 & 162 & $49,982,854$ \\
$2009 / 10$ & $50,033,588$ & 45,767 & 249,386 & 149 & $50,282,974$ \\
$2010 / 11$ & $50,516,168$ & 46,309 & 252,496 & 175 & $50,768,665$ \\
$2011 / 12$ & $51,351,512$ & 38,118 & 253,701 & 114 & $51,605,215$ \\
$2012 / 13$ & $51,635,808$ & 36,917 & 256,294 & 112 & $51,892,104$ \\
$2013 / 14$ & $51,641,720$ & 36,879 & 259,103 & 108 & $51,892,105$ \\
$2014 / 15$ & $51,997,752$ & 35,873 & 260,900 & 125 & $51,892,106$ \\
\hline
\end{tabular}

Source: Authors' calculations based on HBAI data. 
TABLE A3

Comparison of SPI projections and SPI outturns for 'very rich' individuals, 1997/98-2009/10, by stratification group (current prices)

\begin{tabular}{|c|c|c|c|c|c|c|c|c|}
\hline \multirow{2}{*}{ Year } & \multirow{2}{*}{ Stratification group } & \multicolumn{2}{|c|}{ Mean gross income $(£)$} & \multicolumn{2}{|c|}{ Weighted number of individuals } & \multicolumn{3}{|c|}{ Total gross income (£bn) } \\
\hline & & Projection & Outturn & Projection & Outturn & Projection & Outturn & Difference (\%) \\
\hline \multirow{4}{*}{$1997 / 98$} & & 361,577 & 332,387 & 64,447 & 80,740 & 23.3 & 26.8 & -13.2 \\
\hline & GB non-pensioner & & $(9,881)$ & & $(1,354)$ & & $(1.0)$ & \\
\hline & GB pensioner & 101,496 & $\begin{array}{r}83,642 \\
(1,362)\end{array}$ & 50,178 & $\begin{array}{r}52,226 \\
(1,765)\end{array}$ & 5.1 & $\begin{array}{r}4.4 \\
(0.1)\end{array}$ & 16.6 \\
\hline & Total (all groups) & 247,725 & $\begin{array}{r}234,686 \\
(7,032)\end{array}$ & 114,625 & $\begin{array}{r}132,966 \\
(2,262)\end{array}$ & 28.4 & $\begin{array}{r}31.2 \\
(1.0)\end{array}$ & -9.0 \\
\hline \multirow{3}{*}{ 1998/99 } & GB non-pensioner & 550,449 & $\begin{array}{c}527,387 \\
(10,154)\end{array}$ & 35,000 & $\begin{array}{r}45,325 \\
(750)\end{array}$ & 19.3 & $\begin{array}{l}23.9 \\
(0.5)\end{array}$ & -19.4 \\
\hline & GB pensioner & 153,732 & $\begin{array}{r}129,039 \\
(1,766)\end{array}$ & 26,307 & $\begin{array}{r}25,486 \\
(370)\end{array}$ & 4.0 & $\begin{array}{r}3.3 \\
(0.0)\end{array}$ & 23.0 \\
\hline & Total (all groups) & 380,217 & $\begin{array}{r}384,016 \\
(6,942)\end{array}$ & 61,307 & $\begin{array}{r}70,810 \\
(837)\end{array}$ & 23.3 & $\begin{array}{r}27.2 \\
(0.5)\end{array}$ & -14.3 \\
\hline \multirow{3}{*}{$1999 / 00$} & GB non-pensioner & 547,741 & $\begin{array}{r}533,052 \\
(8,361)\end{array}$ & 42,000 & $\begin{array}{r}53,325 \\
(509)\end{array}$ & 23.0 & $\begin{array}{l}28.4 \\
(0.5)\end{array}$ & -19.1 \\
\hline & GB pensioner & 127,425 & $\begin{array}{r}104,744 \\
(1,196)\end{array}$ & 44,053 & $\begin{array}{r}49,143 \\
(833)\end{array}$ & 5.6 & $\begin{array}{r}5.1 \\
(0.1)\end{array}$ & 9.1 \\
\hline & Total (all groups) & 332,569 & $\begin{array}{r}327,639 \\
(5,457)\end{array}$ & 86,053 & $\begin{array}{r}102,468 \\
(996)\end{array}$ & 28.6 & $\begin{array}{l}33.6 \\
(0.5)\end{array}$ & -14.8 \\
\hline \multirow{3}{*}{$2000 / 01$} & GB non-pensioner & 569,533 & $\begin{array}{r}530,661 \\
(7,382)\end{array}$ & 52,517 & $\begin{array}{r}66,425 \\
(915)\end{array}$ & 29.9 & $\begin{array}{l}35.2 \\
(0.6)\end{array}$ & -15.1 \\
\hline & GB pensioner & 157,911 & $\begin{array}{r}108,410 \\
(1,677)\end{array}$ & 50,502 & $\begin{array}{r}50,479 \\
(894)\end{array}$ & 8.0 & $\begin{array}{r}5.5 \\
(0.1)\end{array}$ & 45.7 \\
\hline & Total (all groups) & 367,747 & $\begin{array}{r}348,333 \\
(5,240)\end{array}$ & 103,019 & $\begin{array}{r}116,904 \\
(1,299)\end{array}$ & 37.9 & $\begin{array}{r}40.7 \\
(0.7) \\
\end{array}$ & -7.0 \\
\hline \multirow{3}{*}{$2001 / 02$} & GB non-pensioner & 564,289 & $\begin{array}{r}512,436 \\
(6,393)\end{array}$ & 59,894 & $\begin{array}{r}69,890 \\
(820)\end{array}$ & 33.8 & $\begin{array}{l}35.8 \\
(0.5)\end{array}$ & -5.6 \\
\hline & GB pensioner & 121,984 & $\begin{array}{r}107,229 \\
(1,160)\end{array}$ & 52,818 & $\begin{array}{r}53,431 \\
(500) \\
\end{array}$ & 6.4 & $\begin{array}{r}5.7 \\
(0.0)\end{array}$ & 12.5 \\
\hline & Total (all groups) & 357,020 & $\begin{array}{r}336,872 \\
(4,295)\end{array}$ & 112,712 & $\begin{array}{r}123,321 \\
(1,000)\end{array}$ & 40.2 & $\begin{array}{l}41.5 \\
(0.5)\end{array}$ & -3.1 \\
\hline \multirow{5}{*}{$2002 / 03$} & GB non-pensioner & 567,244 & $\begin{array}{r}501,169 \\
(5,928)\end{array}$ & 62,993 & $\begin{array}{r}67,787 \\
(326)\end{array}$ & 35.7 & $\begin{array}{l}34.0 \\
(0.4)\end{array}$ & 5.2 \\
\hline & NI non-pensioner & 420,365 & $\begin{array}{r}439,427 \\
(76,380)\end{array}$ & 510 & $\begin{array}{l}570 \\
(09)\end{array}$ & 0.2 & $\begin{array}{r}0.3 \\
(0.0)\end{array}$ & -14.5 \\
\hline & GB pensioner & 120,668 & $\begin{array}{r}108,673 \\
(1,130)\end{array}$ & 57,249 & $\begin{array}{r}56,238 \\
(522)\end{array}$ & 6.9 & $\begin{array}{r}6.1 \\
(0.0)\end{array}$ & 13.0 \\
\hline & NI pensioner & 0 & $\begin{array}{r}102,034 \\
(7,416)\end{array}$ & 0 & $\begin{array}{r}1,095 \\
(75)\end{array}$ & 0.0 & $\begin{array}{r}0.1 \\
(0.0)\end{array}$ & -100.0 \\
\hline & Total (all groups) & 354,901 & $\begin{array}{r}321,796 \\
(4,024)\end{array}$ & 120,752 & $\begin{array}{r}125,689 \\
(687) \\
\end{array}$ & 42.9 & $\begin{array}{r}40.4 \\
(0.4) \\
\end{array}$ & 6.0 \\
\hline \multirow{5}{*}{$2003 / 04$} & GB non-pensioner & 523,724 & $\begin{array}{r}508,723 \\
(6,268)\end{array}$ & 63,059 & $\begin{array}{r}70,907 \\
(347)\end{array}$ & 33.0 & $\begin{array}{l}36.1 \\
(0.5)\end{array}$ & -8.4 \\
\hline & NI non-pensioner & 389,902 & $\begin{array}{r}398,281 \\
(29,658)\end{array}$ & 600 & $\begin{array}{r}781 \\
(36)\end{array}$ & 0.2 & $\begin{array}{r}0.3 \\
(0.0)\end{array}$ & -24.8 \\
\hline & GB pensioner & 121,845 & $\begin{array}{r}108,808 \\
(1,064)\end{array}$ & 55,799 & $\begin{array}{r}60,910 \\
(589)\end{array}$ & 6.8 & $\begin{array}{r}6.6 \\
(0.1)\end{array}$ & 2.6 \\
\hline & NI pensioner & 146,802 & $\begin{array}{r}116,779 \\
(8,967)\end{array}$ & 1,100 & $\begin{array}{r}1,039 \\
(80)\end{array}$ & 0.2 & $\begin{array}{r}0.1 \\
(0.0)\end{array}$ & 33.1 \\
\hline & Total (all groups) & 333,613 & $\begin{array}{r}322,755 \\
(4,096)\end{array}$ & 120,558 & $\begin{array}{r}133,637 \\
(760)\end{array}$ & 40.2 & $\begin{array}{l}43.1 \\
(0.5)\end{array}$ & -6.8 \\
\hline \multirow{5}{*}{$2004 / 05$} & GB non-pensioner & 531,573 & $\begin{array}{r}521,025 \\
(5,987)\end{array}$ & 71,220 & $\begin{array}{r}82,226 \\
(428)\end{array}$ & 37.9 & $\begin{array}{r}42.8 \\
(0.5)\end{array}$ & -11.6 \\
\hline & NI non-pensioner & 393,707 & $\begin{array}{r}382,888 \\
(29,851)\end{array}$ & 700 & $\begin{array}{l}888 \\
(30)\end{array}$ & 0.3 & $\begin{array}{r}0.3 \\
(0.0)\end{array}$ & -18.9 \\
\hline & GB pensioner & 123,405 & $\begin{array}{r}106,522 \\
(955)\end{array}$ & 70,985 & $\begin{array}{r}73,499 \\
(692)\end{array}$ & 8.8 & $\begin{array}{r}7.8 \\
(0.1)\end{array}$ & 11.9 \\
\hline & NI pensioner & 153,332 & $\begin{array}{r}121,038 \\
(8,627)\end{array}$ & 1,200 & $\begin{array}{r}1,263 \\
(69)\end{array}$ & 0.2 & $\begin{array}{r}0.2 \\
(0.0)\end{array}$ & 20.3 \\
\hline & Total (all groups) & 326,693 & $\begin{array}{r}324,077 \\
(3,898)\end{array}$ & 144,105 & $\begin{array}{r}157,876 \\
(880)\end{array}$ & 47.1 & $\begin{array}{l}51.2 \\
(0.6)\end{array}$ & -8.0 \\
\hline
\end{tabular}




\begin{tabular}{|c|c|c|c|c|c|c|c|c|}
\hline \multirow[t]{2}{*}{ Year } & \multirow[t]{2}{*}{ Stratification group } & \multicolumn{2}{|c|}{ Mean gross income $(£)$} & \multicolumn{2}{|c|}{ Weighted number of individuals } & \multicolumn{3}{|c|}{ Total gross income (£bn) } \\
\hline & & Projection & Outturn & Projection & Outturn & Projection & Outturn & Difference (\%) \\
\hline \multirow{5}{*}{$2005 / 06$} & GB non-pensioner & 540,265 & $\begin{array}{r}529,534 \\
(5,754)\end{array}$ & 72,673 & $\begin{array}{r}108,904 \\
(483)\end{array}$ & 39.3 & $\begin{array}{l}57.7 \\
(0.6)\end{array}$ & -31.9 \\
\hline & NI non-pensioner & 391,186 & $\begin{array}{r}431,422 \\
(37,125)\end{array}$ & 900 & $\begin{array}{r}1,138 \\
(35)\end{array}$ & 0.4 & $\begin{array}{r}0.5 \\
(0.0)\end{array}$ & -28.3 \\
\hline & GB pensioner & 122,515 & $\begin{array}{r}108,102 \\
(919)\end{array}$ & 72,214 & $\begin{array}{r}90,344 \\
(728)\end{array}$ & 8.8 & $\begin{array}{r}9.8 \\
(0.1)\end{array}$ & -9.4 \\
\hline & NI pensioner & 148,603 & $\begin{array}{r}119,001 \\
(7,878)\end{array}$ & 1,400 & $\begin{array}{r}1,379 \\
(72) \\
\end{array}$ & 0.2 & $\begin{array}{r}0.2 \\
(0.0) \\
\end{array}$ & 26.8 \\
\hline & Total (all groups) & 330,669 & $\begin{array}{r}337,471 \\
(3,736)\end{array}$ & 147,187 & $\begin{array}{r}201,765 \\
(947) \\
\end{array}$ & 48.7 & $\begin{array}{r}68.1 \\
(0.7) \\
\end{array}$ & -28.5 \\
\hline \multirow{5}{*}{$2006 / 07$} & GB non-pensioner & 538,304 & $\begin{array}{r}540,823 \\
(5,529)\end{array}$ & 89,304 & $\begin{array}{r}130,357 \\
(516)\end{array}$ & 48.1 & $\begin{array}{r}70.5 \\
(0.7)\end{array}$ & -31.8 \\
\hline & NI non-pensioner & 398,104 & $\begin{array}{r}409,869 \\
(24,479)\end{array}$ & 900 & $\begin{array}{r}1,792 \\
(53)\end{array}$ & 0.4 & $\begin{array}{r}0.7 \\
(0.0)\end{array}$ & -51.2 \\
\hline & GB pensioner & 117,478 & $\begin{array}{r}107,860 \\
(861)\end{array}$ & 96,361 & $\begin{array}{r}104,746 \\
(869)\end{array}$ & 11.3 & $\begin{array}{r}11.3 \\
(0.1)\end{array}$ & 0.2 \\
\hline & NI pensioner & 117,431 & $\begin{array}{r}128,089 \\
(8,818) \\
\end{array}$ & 925 & $\begin{array}{r}1,620 \\
(82) \\
\end{array}$ & 0.1 & $\begin{array}{r}0.2 \\
(0.0) \\
\end{array}$ & -47.7 \\
\hline & Total (all groups) & 319,270 & $\begin{array}{r}346,897 \\
(3,612) \\
\end{array}$ & 187,490 & $\begin{array}{r}238,515 \\
(1,088) \\
\end{array}$ & 59.9 & $\begin{array}{r}82.7 \\
(0.8) \\
\end{array}$ & -27.7 \\
\hline \multirow{5}{*}{$2007 / 08$} & GB non-pensioner & 560,402 & $\begin{array}{r}569,438 \\
(6,610)\end{array}$ & 111,301 & $\begin{array}{r}145,754 \\
(718)\end{array}$ & 62.4 & $\begin{array}{r}83.0 \\
(1.0)\end{array}$ & -24.8 \\
\hline & NI non-pensioner & 450,003 & $\begin{array}{l}440,504 \\
(30,601)\end{array}$ & 1,300 & $\begin{array}{l}1,993 \\
(120)\end{array}$ & 0.6 & $\begin{array}{r}0.9 \\
(0.1)\end{array}$ & -33.4 \\
\hline & GB pensioner & 123,087 & $\begin{array}{r}109,908 \\
(810)\end{array}$ & 122,029 & $\begin{array}{r}124,307 \\
(959)\end{array}$ & 15.0 & $\begin{array}{l}13.7 \\
(0.1)\end{array}$ & 9.9 \\
\hline & NI pensioner & 122,423 & $\begin{array}{r}113,889 \\
(6,182) \\
\end{array}$ & 2,201 & $\begin{array}{r}2,492 \\
(97) \\
\end{array}$ & 0.3 & $\begin{array}{r}0.3 \\
(0.0) \\
\end{array}$ & -5.1 \\
\hline & Total (all groups) & 330,396 & $\begin{array}{r}356,304 \\
(4,061) \\
\end{array}$ & 236,831 & $\begin{array}{r}274,545 \\
(1,282) \\
\end{array}$ & 78.2 & $\begin{array}{r}97.8 \\
(1.1) \\
\end{array}$ & -20.0 \\
\hline \multirow{5}{*}{$2009 / 10$} & GB non-pensioner & 644,261 & $\begin{array}{r}720,214 \\
(8,626)\end{array}$ & 111,062 & $\begin{array}{r}113,807 \\
(445)\end{array}$ & 71.6 & $\begin{array}{r}82.0 \\
(1.0)\end{array}$ & -12.7 \\
\hline & NI non-pensioner & 317,331 & $\begin{array}{r}386,949 \\
(34,682)\end{array}$ & 3,300 & $\begin{array}{r}2,603 \\
(70)\end{array}$ & 1.0 & $\begin{array}{r}1.0 \\
(0.1)\end{array}$ & 4.0 \\
\hline & GB pensioner & 125,886 & $\begin{array}{r}117,078 \\
(983)\end{array}$ & 103,230 & $\begin{array}{r}131,716 \\
(748)\end{array}$ & 13.0 & $\begin{array}{r}15.4 \\
(0.1)\end{array}$ & -15.7 \\
\hline & NI pensioner & 119,899 & $\begin{array}{r}110,220 \\
(6,822)\end{array}$ & 3,299 & $\begin{array}{r}3,435 \\
(154)\end{array}$ & 0.4 & $\begin{array}{r}0.4 \\
(0.0)\end{array}$ & 4.5 \\
\hline & Total (all groups) & 389,291 & $\begin{array}{r}392,638 \\
(4,605) \\
\end{array}$ & 220,891 & $\begin{array}{r}251,560 \\
(966) \\
\end{array}$ & 86.0 & $\begin{array}{r}98.8 \\
(1.1) \\
\end{array}$ & -12.9 \\
\hline
\end{tabular}

Notes. Projections are taken from HBAI-SPI data; Outturns are taken from SPI outturn data. Women aged 55-64 are excluded as their pensioner status cannot be determined in the SPI data for years before 2010/11. In the HBAI, this group represents between $1.7 \%$ in $1997 / 98$ and $11.7 \%$ in $2005 / 06$ of the individuals deemed 'very rich'. See main text for further discussion.

Source: Authors' calculations based on SPI and HBAI-SPI data. 
TABLE A4

Summary of SPI adjustments to individual gross income and grossing-up factors

1994/95-2014/15

\begin{tabular}{|c|c|c|c|c|c|c|c|c|c|c|c|c|}
\hline \multirow[b]{3}{*}{ Year } & \multirow[b]{3}{*}{ Group } & & \multirow{3}{*}{$\begin{array}{l}\text { No. } \\
\text { of } \\
\text { SPI- } \\
\text { adjust } \\
\text { ed } \\
\text { cases }\end{array}$} & \multicolumn{7}{|c|}{ Income adjustments } & \multirow{2}{*}{\multicolumn{2}{|c|}{$\begin{array}{l}\text { Adjustment to } \\
\text { grossing-up } \\
\text { factors }\end{array}$}} \\
\hline & & & & \multirow{2}{*}{$\begin{array}{l}\text { Mean } \\
\text { income } \\
\text { adjust- } \\
\text { ment }\end{array}$} & \multicolumn{3}{|c|}{$\begin{array}{c}\text { Cases with upward } \\
\text { adjustment }\end{array}$} & \multicolumn{3}{|c|}{$\begin{array}{c}\text { Cases with downward } \\
\text { adjustment }\end{array}$} & & \\
\hline & & & & & No. & $\begin{array}{l}\text { Mean } \\
\text { change }\end{array}$ & $\begin{array}{l}\text { Median } \\
\text { change }\end{array}$ & No. & $\begin{array}{l}\text { Mean } \\
\text { change }\end{array}$ & $\begin{array}{c}\text { Median } \\
\text { change }\end{array}$ & $\begin{array}{l}\text { Mean } \\
\text { change }\end{array}$ & $\begin{array}{c}\% \\
\text { change }\end{array}$ \\
\hline \multirow[t]{2}{*}{$1994 / 95$} & $\begin{array}{l}\text { Non- } \\
\text { pens }\end{array}$ & GB & 52 & 3,584 & 49 & 4,715 & 4,861 & 3 & $-14,904$ & $-18,354$ & -266 & -26 \\
\hline & Pens. & GB & 25 & 471 & 19 & 910 & 993 & 6 & -921 & -987 & 660 & 72 \\
\hline \multirow[t]{2}{*}{$1995 / 96$} & $\begin{array}{l}\text { Non- } \\
\text { pens }\end{array}$ & GB & 40 & 3,368 & 36 & 4,348 & 4,629 & 4 & $-5,449$ & $-6,140$ & 209 & 23 \\
\hline & Pens. & GB & 5 & 2,187 & 5 & 2,187 & 2,651 & 0 & 0 & 0 & 399 & 45 \\
\hline \multirow[t]{2}{*}{$1996 / 97$} & $\begin{array}{l}\text { Non- } \\
\text { pens }\end{array}$ & GB & 54 & 2,836 & 47 & 4,331 & 4,874 & 7 & $-7,204$ & -850 & -45 & -5 \\
\hline & Pens. & GB & 7 & 1,670 & 6 & 2,352 & 2,821 & 1 & $-2,423$ & $-2,423$ & 387 & 43 \\
\hline \multirow[t]{2}{*}{$1997 / 98$} & $\begin{array}{l}\text { Non- } \\
\text { pens }\end{array}$ & GB & 68 & 4,887 & 65 & 5,239 & 5,532 & 3 & $-2,750$ & $-3,108$ & -126 & -12 \\
\hline & Pens. & GB & 30 & 453 & 24 & 825 & 897 & 6 & $-1,037$ & -539 & 715 & 74 \\
\hline \multirow[t]{2}{*}{$1998 / 99$} & $\begin{array}{l}\text { Non- } \\
\text { pens }\end{array}$ & GB & 24 & 3,983 & 20 & 7,967 & 8,456 & 4 & $-15,935$ & $-19,332$ & 407 & 41 \\
\hline & Pens. & GB & 22 & 187 & 16 & 1,500 & 1,709 & 6 & $-3,314$ & $-2,127$ & 293 & 29 \\
\hline \multirow[t]{2}{*}{$1999 / 00$} & $\begin{array}{l}\text { Non- } \\
\text { pens }\end{array}$ & GB & 28 & 4,433 & 24 & 7,019 & 8,307 & 4 & $-11,080$ & $-9,811$ & 525 & 58 \\
\hline & Pens. & GB & 28 & 968 & 25 & 1,446 & 1,555 & 3 & $-3,016$ & $-1,843$ & 634 & 63 \\
\hline \multirow[t]{2}{*}{$2000 / 01$} & $\begin{array}{l}\text { Non- } \\
\text { pens }\end{array}$ & GB & 47 & $-1,218$ & 29 & 7,882 & 8,230 & 18 & $-15,880$ & $-9,422$ & -13 & -1 \\
\hline & Pens. & GB & 37 & 1,705 & 34 & 2,152 & 2,417 & 3 & $-3,362$ & $-3,234$ & 522 & 55 \\
\hline \multirow[t]{2}{*}{$2001 / 02$} & $\begin{array}{l}\text { Non- } \\
\text { pens }\end{array}$ & GB & 43 & $-4,763$ & 36 & 7,284 & 7,626 & 7 & $-66,714$ & $-6,362$ & 461 & 50 \\
\hline & Pens. & GB & 56 & 473 & 42 & 1,281 & 1,448 & 14 & $-1,953$ & -994 & 169 & 18 \\
\hline \multirow{4}{*}{$2002 / 03$} & Non- & GB & 42 & 7,016 & 40 & 7,858 & 8,229 & 2 & $-9,814$ & $-9,814$ & 473 & 51 \\
\hline & pens. & NI & 2 & 1,687 & 1 & 6,226 & 6,226 & 1 & $-2,853$ & $-2,853$ & -22 & -7 \\
\hline & Pens. & GB & 49 & -55 & 38 & 1,319 & 1,409 & 11 & $-4,800$ & $-1,672$ & 398 & 48 \\
\hline & & NI & 0 & 0 & 0 & 0 & 0 & 0 & 0 & 0 & 0 & 0 \\
\hline \multirow{4}{*}{$2003 / 04$} & Non- & GB & 46 & 3,013 & 38 & 6,457 & 6,244 & 8 & $-13,346$ & $-12,370$ & 429 & 47 \\
\hline & pens. & NI & 1 & 5,708 & 1 & 5,708 & 5,708 & 0 & 0 & 0 & 294 & 96 \\
\hline & Pens & GB & 66 & 458 & 52 & 1,241 & 1,424 & 14 & $-2,452$ & $-1,069$ & 150 & 17 \\
\hline & & NI & 2 & -327 & 0 & 0 & 0 & 2 & -327 & -327 & 236 & 75 \\
\hline \multirow{4}{*}{$2004 / 05$} & Non- & GB & 50 & 4,401 & 44 & 5,770 & 6,584 & 6 & $-5,643$ & $-4,940$ & 423 & 46 \\
\hline & pens. & NI & 2 & 3,613 & 2 & 3,613 & 3,613 & 0 & 0 & 0 & -50 & -7 \\
\hline & & GB & 74 & 845 & 64 & 1,249 & 1,389 & 10 & $-1,742$ & $-1,660$ & 175 & 21 \\
\hline & Pens. & NI & 1 & 1,896 & 1 & 1,896 & 1,896 & 0 & 0 & 0 & 943 & 367 \\
\hline \multirow{4}{*}{$2005 / 06$} & Non- & GB & 53 & $-4,981$ & 43 & 4,910 & 5,546 & 10 & $-47,509$ & $-5,488$ & 462 & 51 \\
\hline & pens. & NI & 1 & 1,631 & 1 & 1,631 & 1,631 & 0 & 0 & 0 & 346 & 62 \\
\hline & & GB & 70 & 688 & 64 & 1,158 & 1,227 & 6 & $-4,333$ & $-1,697$ & 401 & 46 \\
\hline & $\mathrm{P}$ & NI & 2 & 2,091 & 2 & 2,091 & 2,091 & 0 & 0 & 0 & 388 & 126 \\
\hline \multirow{4}{*}{$2006 / 07$} & Non- & GB & 57 & 3,639 & 45 & 6,263 & 6,194 & 12 & $-6,202$ & $-5,414$ & 402 & 37 \\
\hline & pens. & NI & 2 & 2,774 & 2 & 2,774 & 2,774 & 0 & 0 & 0 & 149 & 46 \\
\hline & & GB & 70 & 218 & 56 & 939 & 1,128 & 14 & $-2,666$ & -931 & 617 & 66 \\
\hline & & NI & 2 & 1,086 & 2 & 1,086 & 1,086 & 0 & 0 & 0 & 652 & 228 \\
\hline
\end{tabular}




\begin{tabular}{|c|c|c|c|c|c|c|c|c|c|c|c|c|}
\hline \multirow[b]{3}{*}{ Year } & \multirow[b]{3}{*}{ Group } & & \multirow{3}{*}{$\begin{array}{c}\text { No. } \\
\text { of } \\
\text { SPI- } \\
\text { adjust } \\
\text { ed } \\
\text { cases }\end{array}$} & \multicolumn{7}{|c|}{ Income adjustments } & \multirow{2}{*}{\multicolumn{2}{|c|}{$\begin{array}{l}\text { Adjustment to } \\
\text { grossing-up } \\
\text { factors }\end{array}$}} \\
\hline & & & & \multirow{2}{*}{$\begin{array}{l}\text { Mean } \\
\text { income } \\
\text { adjust- } \\
\text { ment }\end{array}$} & \multicolumn{3}{|c|}{$\begin{array}{c}\text { Cases with upward } \\
\text { adjustment }\end{array}$} & \multicolumn{3}{|c|}{$\begin{array}{c}\text { Cases with downward } \\
\text { adjustment }\end{array}$} & & \\
\hline & & & & & No. & $\begin{array}{c}\text { Mean } \\
\text { change }\end{array}$ & $\begin{array}{c}\text { Median } \\
\text { change }\end{array}$ & No. & $\begin{array}{c}\text { Mean } \\
\text { change }\end{array}$ & $\begin{array}{l}\text { Median } \\
\text { change }\end{array}$ & $\begin{array}{c}\text { Mean } \\
\text { change }\end{array}$ & $\begin{array}{c}\% \\
\text { change }\end{array}$ \\
\hline \multirow{4}{*}{$2007 / 08$} & \multirow{2}{*}{$\begin{array}{l}\text { Non- } \\
\text { pens. }\end{array}$} & GB & 59 & 5,188 & 51 & 6,482 & 6,934 & 8 & $-3,061$ & $-2,544$ & 578 & 51 \\
\hline & & NI & 3 & 3,455 & 3 & 3,455 & 3,618 & 0 & 0 & 0 & 34 & 8 \\
\hline & \multirow{2}{*}{ Pens. } & GB & 68 & 455 & 54 & 1,062 & 1,150 & 14 & $-1,887$ & -514 & 942 & 88 \\
\hline & & NI & 6 & 650 & 5 & 917 & 928 & 1 & -685 & -685 & 66 & 21 \\
\hline \multirow{4}{*}{$2008 / 09$} & \multirow{2}{*}{$\begin{array}{l}\text { Non- } \\
\text { pens. }\end{array}$} & GB & 63 & $-1,139$ & 52 & 6,806 & 7,024 & 11 & $-38,699$ & $-5,733$ & 662 & 60 \\
\hline & & NI & 4 & 3,664 & 4 & 3,664 & 3,694 & 0 & 0 & 0 & 464 & 139 \\
\hline & \multirow{2}{*}{ Pens. } & GB & 88 & 375 & 68 & 1,055 & 1,185 & 20 & $-1,938$ & $-1,348$ & 383 & 35 \\
\hline & & NI & 7 & 968 & 7 & 968 & 1,170 & 0 & 0 & 0 & 38 & 14 \\
\hline \multirow{4}{*}{$2009 / 10$} & \multirow{2}{*}{$\begin{array}{l}\text { Non- } \\
\text { pens. }\end{array}$} & GB & 43 & 1,251 & 31 & 5,797 & 6,214 & 12 & $-10,492$ & $-5,832$ & 1285 & 121 \\
\hline & & NI & 2 & 309 & 2 & 309 & 309 & 0 & 0 & 0 & 1250 & 329 \\
\hline & \multirow{2}{*}{ Pens. } & GB & 100 & 238 & 79 & 997 & 1,078 & 21 & $-2,616$ & $-1,094$ & 297 & 30 \\
\hline & & NI & 4 & 494 & 4 & 494 & 521 & 0 & 0 & 0 & 553 & 207 \\
\hline \multirow{4}{*}{$2010 / 11$} & \multirow{2}{*}{$\begin{array}{l}\text { Non- } \\
\text { pens. }\end{array}$} & GB & 85 & 1,782 & 65 & 5,177 & 6,236 & 20 & $-9,252$ & $-6,257$ & 170 & 14 \\
\hline & & NI & 7 & $-1,990$ & 3 & 2,218 & 2,265 & 4 & $-5,146$ & $-4,878$ & 68 & 18 \\
\hline & \multirow{2}{*}{ Pens. } & GB & 79 & 702 & 68 & 1,048 & 1,170 & 11 & $-1,436$ & -466 & 691 & 69 \\
\hline & & NI & 4 & $-1,023$ & 3 & 1,140 & 1,245 & 1 & $-7,514$ & $-7,514$ & 450 & 149 \\
\hline \multirow{4}{*}{$2011 / 12$} & \multirow{2}{*}{$\begin{array}{l}\text { Non- } \\
\text { pens. }\end{array}$} & GB & 44 & 4,289 & 38 & 5,771 & 6,251 & 6 & $-5,091$ & $-3,793$ & 1038 & 73 \\
\hline & & NI & 4 & 1,862 & 4 & 1,862 & 1,881 & 0 & 0 & 0 & 528 & 162 \\
\hline & \multirow{2}{*}{ Pens. } & GB & 63 & 546 & 52 & 905 & 986 & 11 & $-1,155$ & -615 & 840 & 69 \\
\hline & & NI & 3 & 888 & 3 & 888 & 772 & 0 & 0 & 0 & 800 & 247 \\
\hline \multirow{4}{*}{$2012 / 13$} & \multirow{2}{*}{$\begin{array}{l}\text { Non- } \\
\text { pens. }\end{array}$} & GB & 35 & 3,000 & 28 & 4,736 & 5,252 & 7 & $-3,943$ & $-3,362$ & 1609 & 110 \\
\hline & & NI & 2 & 715 & 2 & 715 & 715 & 0 & 0 & 0 & 1387 & 442 \\
\hline & Pens & GB & 69 & 245 & 57 & 992 & 1,118 & 12 & $-3,302$ & -924 & 636 & 49 \\
\hline & & NI & 6 & 289 & 5 & 727 & 844 & 1 & $-1,905$ & $-1,905$ & 245 & 76 \\
\hline & Non- & GB & 22 & $-10,993$ & 20 & 5,273 & 6,671 & 2 & $-173,651$ & $-173,651$ & 3705 & 245 \\
\hline 20 & pens. & NI & 5 & 936 & 4 & 1,651 & 1,709 & 1 & $-1,920$ & $-1,920$ & 385 & 131 \\
\hline $2013 / 14$ & Dons & GB & 74 & 1,191 & 69 & 1,352 & 1,458 & 5 & $-1,032$ & -819 & 554 & 42 \\
\hline & Pens. & NI & 7 & 522 & 6 & 731 & 805 & 1 & -728 & -728 & 92 & 25 \\
\hline & Non- & GB & 36 & 4,082 & 31 & 5,520 & 6,495 & 5 & $-4,837$ & $-4,860$ & 1686 & 117 \\
\hline 201 & pens. & NI & 4 & 1,708 & 4 & 1,708 & 1,684 & 0 & 0 & 0 & 321 & 84 \\
\hline $2014 / 15$ & & GB & 82 & 873 & 71 & 1,291 & 1,453 & 11 & $-1,826$ & -835 & 247 & 18 \\
\hline & & NI & 3 & 578 & 3 & 578 & 479 & 0 & 0 & 0 & 732 & 208 \\
\hline
\end{tabular}

Notes: Northern Ireland is included only from 2002/03 onwards. All reported mean and median income adjustments are in pounds per week (2014/15 prices). GB: Great Britain (England, Wales, Scotland). NI: Northern Ireland. Estimated standard errors in parentheses.

Sources: Authors' calculations from FRS and HBAI data. 
FIGURE A1

Gini coefficients before and after the SPI adjustments (individual gross income)

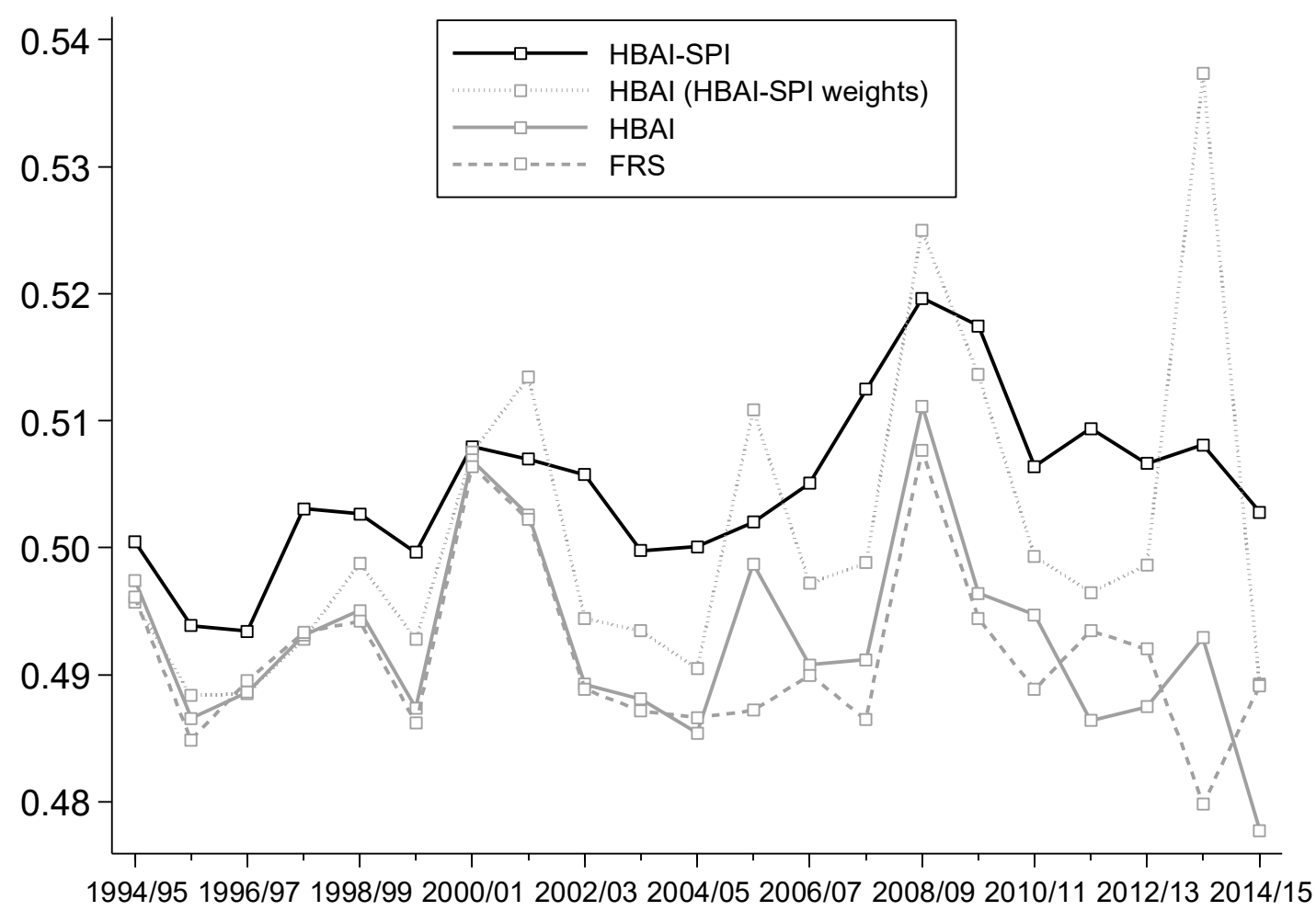

Notes: Income refers to individual-level gross income (by contrast with Figure 5 which refers to equivalised household net income). The individual is the unit of analysis. Estimates are based on the population aged 15+. Northern Ireland is included only from 2002/03 onwards. See Section II for further details of the different series.

Source: Authors' calculations based on FRS and HBAI data.

(Stata graph Ginilh_ind) 
FIGURE A2

Mean logarithmic deviation (MLD) with and without SPI adjustments (equivalised household net income)

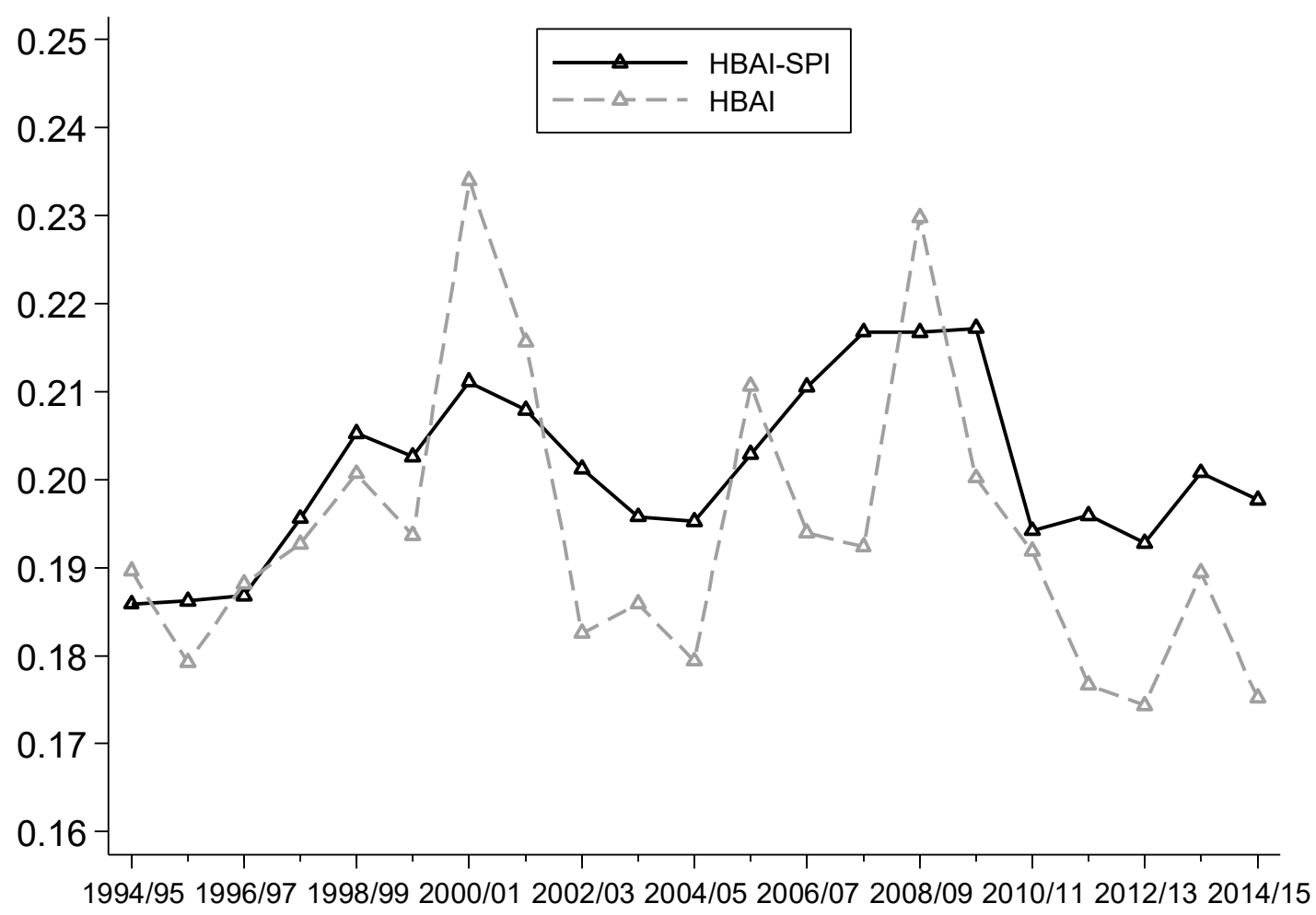

Notes: In each series, the distribution is of equivalised household net income among all individuals. Northern Ireland is included only from 2002/03 onwards. The income definition and series acronyms are explained in Section II.

Source: Authors' calculations based on FRS and HBAI data.

(Stata graph I0) 
FIGURE A3

Theil index with and without SPI adjustments (equivalised household net income)

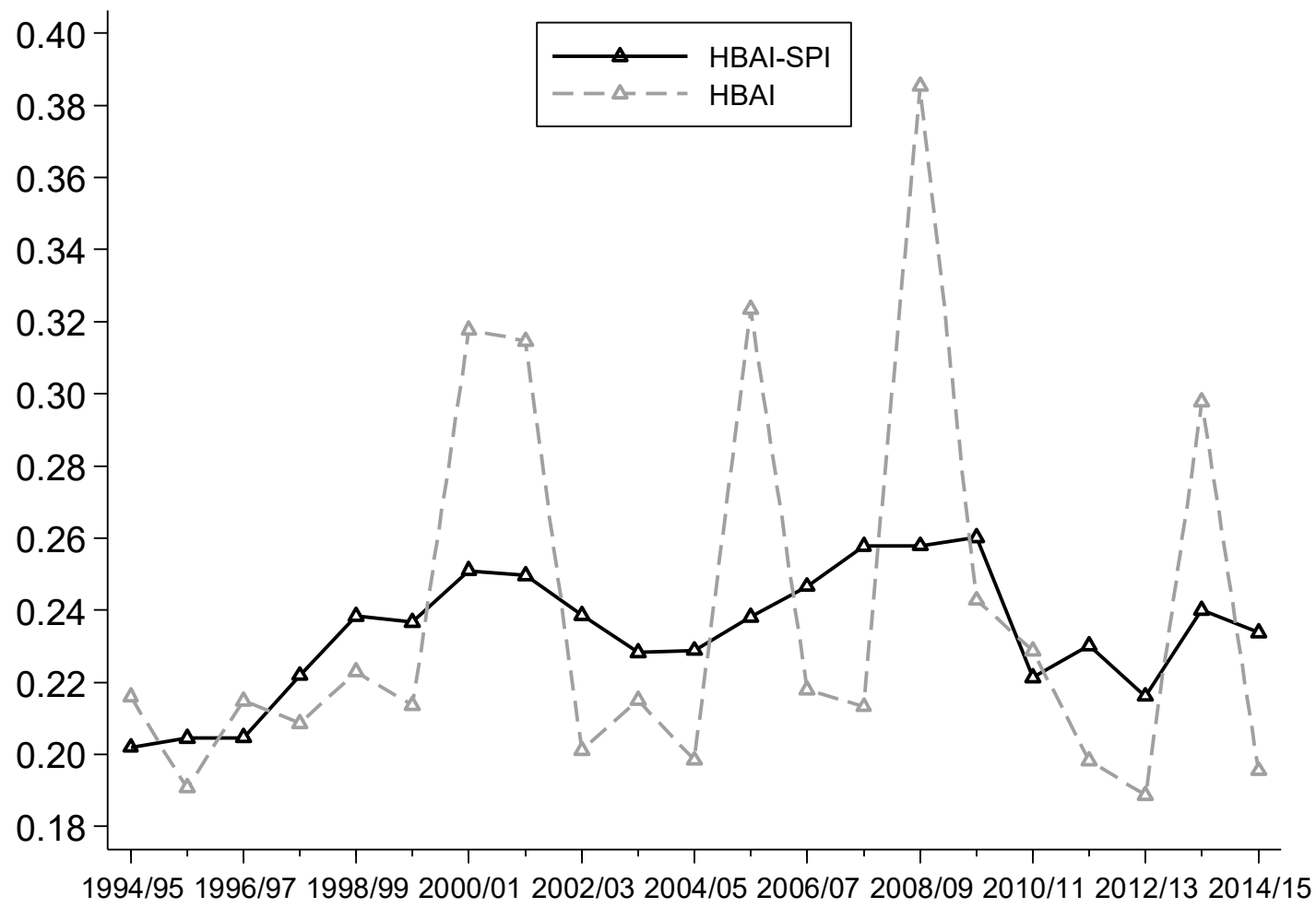

Notes: As for Figure A2.

Source: Authors' calculations based on FRS and HBAI data.

(Stata graph I1) 
FIGURE A4

Half squared coefficient of variation with and without SPI adjustments (equivalised household net income)

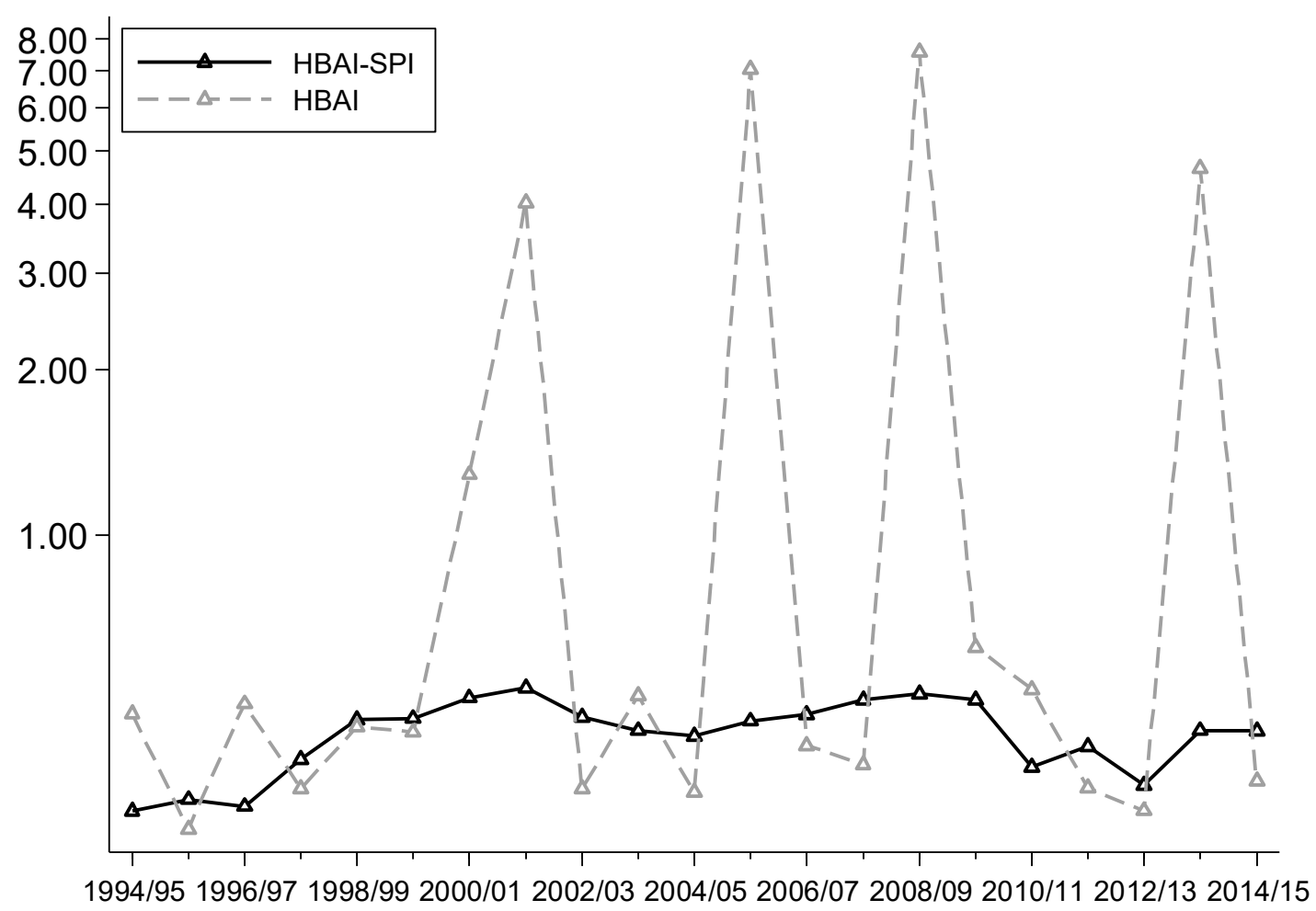

Notes: As for Figure A2.

Source: Authors' calculations based on FRS and HBAI data.

(Stata graph I2) 